\title{
A Balance Sheet Approach to Financial Crisis
}

Mark Allen, Christoph Rosenberg,

Christian Keller, Brad Setser, and Nouriel Roubini 


\title{
IMF Working Paper
}

\author{
Policy Development and Review Department
}

\section{A Balance Sheet Approach to Financial Crisis}

\author{
Prepared by Mark Allen, Christoph Rosenberg, Christian Keller, \\ Brad Setser, and Nouriel Roubini ${ }^{1}$
}

Authorized for distribution by Timothy Geithner

December 2002

\begin{abstract}
The views expressed in this Working Paper are those of the author(s) and do not necessarily represent those of the IMF or IMF policy. Working Papers describe research in progress by the author(s) and are published to elicit comments and to further debate.
\end{abstract}

The paper lays out an analytical framework for understanding crises in emerging markets based on examination of stock variables in the aggregate balance sheet of a country and the balance sheets of its main sectors (assets and liabilities). It focuses on the risks created by maturity, currency, and capital structure mismatches. This framework draws attention to the vulnerabilities created by debts among residents, particularly those denominated in foreign currency, and it helps to explain how problems in one sector can spill over into other sectors, eventually triggering an external balance of payments crisis. The paper also discusses the potential of macroeconomic policies and official intervention to mitigate the cost of such a crisis.

JEL Classification Numbers: E00, F02, F32, F33, F34, F42, G15, G18

Keywords: National balance sheets, financial crisis, IMF policy, emerging markets

Authors’ E-Mail Addresses: mallen2@imf.org, crosenberg@imf.org, ckeller@imf.org, bsetser@imf.org,nroubini@stern.nyu.edu

\footnotetext{
${ }^{1}$ The first four authors are Deputy Director, Deputy Division Chief, Economist and Consultant, respectively, in the Policy Review and Development Department of the IMF. Nouriel Roubini is a professor at New York University, who spent some months as a Visiting Scholar at the IMF. The authors would like to thank Anne Krueger, Timothy Geithner, Leslie Lipschitz, Charles Enoch, Alan MacArthur, Christian Mulder, Jeromin Zettelmeyer, Olivier Jeanne and reviewers in several departments of the Fund for extensive comments. All remaining errors are ours.
} 


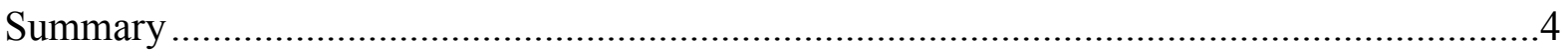

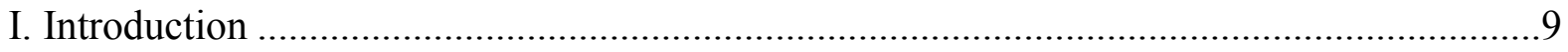

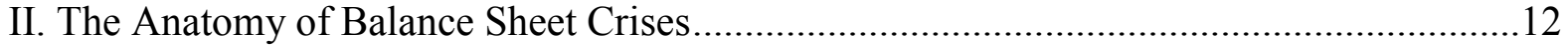

A. Balance Sheet Concepts: A Primer with Examples ................................................... 12

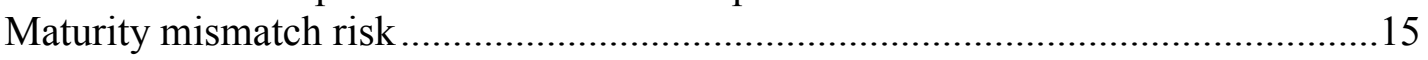

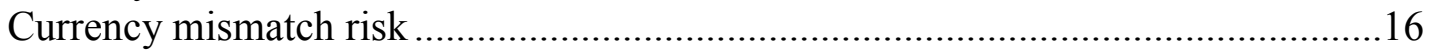

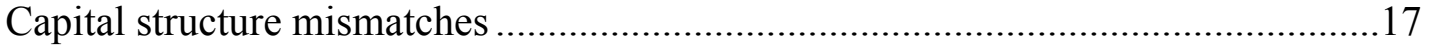

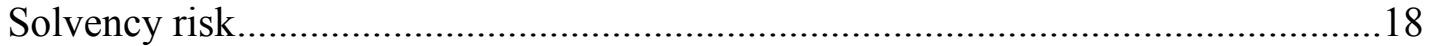

Related risks ......................................................................................... 20

B. Characteristics of Recent Capital Account Crises from a Balance Sheet

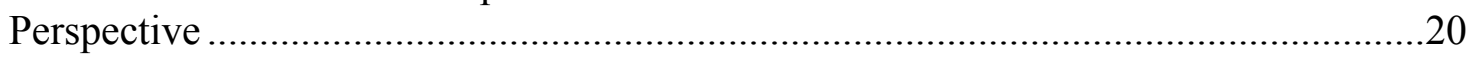

III. Implications for Crisis Prevention and Fund Policy Advice During Crises .....................23

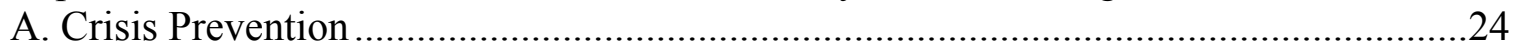

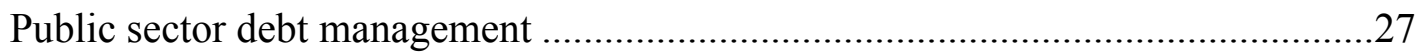

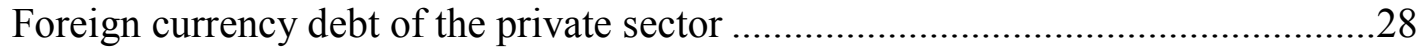

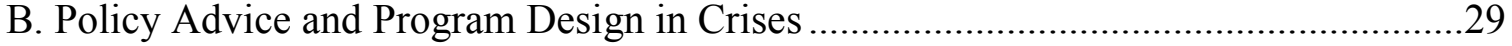

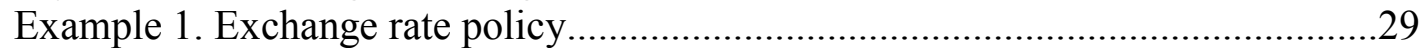

Example 2. Monetary policy and foreign exchange intervention after a

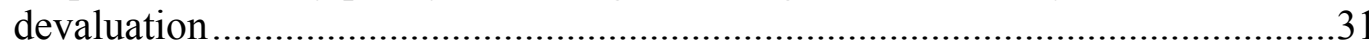

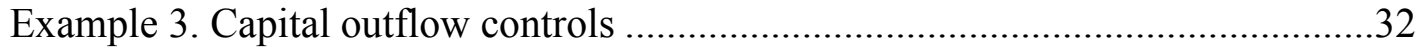

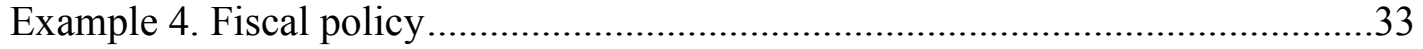

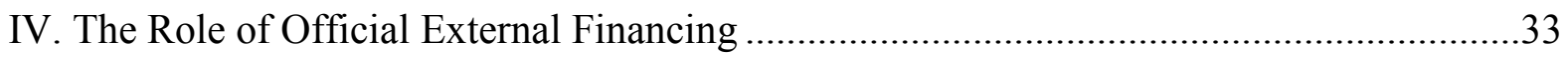

A. The Need for External Financing ........................................................................... 34

B. The Case for Official External Financing or Official Support for a Debt

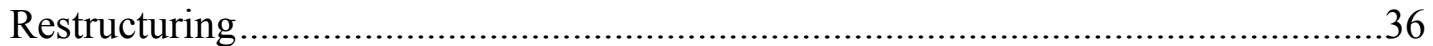

C. Limits on Use of External Official Financing to Address Balance Sheet

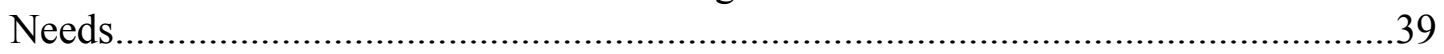

D. Sustainability of Balance Sheets ........................................................................ 41

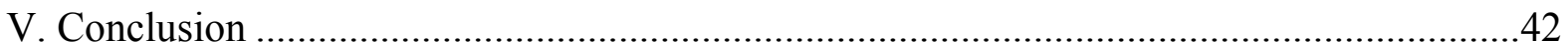

Annex I

Estimating Balance Sheet Needs: Operational Issues..................................................44

Annex II

Calculating Balance Sheet Risks and Financing Gaps: Thailand Before the Crisis...............50

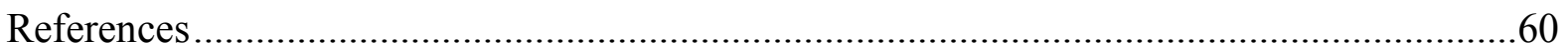


Boxes

1. The Balance Sheet Approach in Recent Academic Literature............................................10

2. How Balance Sheet Risks Apply to Different Sectors....................................................19

3. Balance Sheet Approach and Flow Analysis .............................................................24

4. Data Availability as Prerequisite for Balance Sheet Analysis .......................................25

Figure

1. Financial Interlinkages Between the Sectors in an Economy .........................................14

Table

1. Indicators of Potential Financing Needs in Recent Capital Account Crises.....................23

Annex I Figure

1. Matrix of an Economy's Intersectoral Asset and Liability Positions

Annex II Figures

1. Thailand: Intersectoral Asset and Liability Position End of December 1996 .51

2. Thailand: Intersectoral Asset and Liability Position End of June 1997.

Annex II Tables

1. Thailand: External Foreign Currency Financing Gaps, December 1996. .55

2. Thailand: External Foreign Currency Financing Gaps, June 1997 .................................56

3. Average Corporate Debt-to-Equity Ratios in Selected Countries ....................................58

4. Financial Institutions' Claims on the Private Sector in Selected Countries, End of 1996...58 


\section{SUMMARY}

Financial markets have become increasingly integrated over the past ten years. In many countries, foreign borrowing has helped to finance higher levels of investment than would be possible with domestic savings alone and contributed to sustained periods of growth. But the opening of capital markets has also placed exceptional demands on financial and macroeconomic policies in emerging market economies. Private capital flows are sensitive to market conditions, perceived policy weaknesses, and negative shocks. Flows of private capital have been more volatile than many expected. A number of major emerging economies have experienced sharp financial crises since 1994.

The financial structure of many emerging markets economies - the composition and size of the liabilities and assets on the country's financial balance sheet - has been an important source of vulnerability to crises. Financial weaknesses, such as a high level of short-term debt, can be a trigger for domestic and external investors to reassess their willingness to finance a country. The composition of a country's financial balance sheets also helps to determine how much time a country might have to overcome doubts about the strength of its macroeconomic policy framework, and, more generally, how effectively a country can insulate itself from volatility stemming from changes in global market conditions.

This paper seeks to lay out a systematic analytical framework for exploring how balance sheet weaknesses contribute to the origin and propagation of modern-day financial crises. It draws on the growing body of academic work that emphasizes the importance of balance sheets. It pays particular attention to the balance sheets of key sectors of the economy and explores how weaknesses in one sector can cascade and ultimately generate a broader crisis.

\section{What Is the Balance Sheet Approach?}

Unlike traditional analysis, which is based on the examination of flow variables (such as current account and fiscal balance), the balance sheet approach focuses on the examination of stock variables in a country's sectoral balance sheets and its aggregate balance sheet (assets and liabilities). From this perspective, a financial crisis occurs when there is a plunge in demand for financial assets of one or more sectors: creditors may lose confidence in a country's ability to earn foreign exchange to service the external debt, in the government's ability to service its debt, in the banking system's ability to meet deposit outflows, or in corporations' ability to repay bank loans and other debt. An entire sector may be unable to attract new financing or roll over existing short-term liabilities. It must then either find the resources to pay off its debts or seek a restructuring. Ultimately, a plunge in demand for the country's assets leads to a surge in demand for foreign assets and/or for assets denominated in foreign currency. Massive outflows of capital, a sharp depreciation of the exchange rate, a large current account surplus, and a deep recession that reduces domestic absorption are often the necessary counterpart to a sudden adjustment in investors' willingness to hold a country's accumulated stock of financial assets. 
An economy's resilience to a range of shocks, including financial shocks, hinges in part on the composition of the country's stock of liabilities and assets. The country's aggregate balance sheet - the external liabilities and liquid external assets of all sectors of the economy - is vital. But it is often equally important to look inside an economy and to examine the balance sheet of an economy's key sectors, such as the government, the financial sector, and the corporate sector.

Our framework for assessing balance sheet risks focuses on four types of balance sheet mismatches, all of which help to determine a country's ability to service debt in the face of shocks: (i) maturity mismatches, where a gap between liabilities due in the short term and liquid assets leaves a sector unable to honor its contractual commitments if the market declines to roll over debt, or creates exposure to the risk that interest rates will rise; (ii) currency mismatches, where a change in the exchange rate leads to a capital loss; (iii) capital structure problems, where a heavy reliance on debt rather than equity financing leaves a firm or bank less able to weather revenue shocks; and (iv) solvency problems, where assets - including the present value of future revenue streams - are insufficient to cover liabilities, including contingent liabilities. Maturity mismatches, currency mismatches, and a poor capital structure all can contribute to solvency risk, but solvency risk can also arise from simply borrowing too much or from investing in low-yielding assets.

An analytical framework that examines the balance sheets of an economy's major sectors for maturity, currency, and capital structure mismatches helps to highlight how balance sheet problems in one sector can spill over into other sectors, and eventually trigger an external balance of payments crisis. Indeed, one of the core arguments that emerges from this approach is that the debts among residents that create internal balance sheet mismatches also generate vulnerability to an external balance of payments crisis. The transmission mechanism often works through the domestic banking system. For instance, broad concerns about the government's ability to service its debt, whether denominated in domestic or foreign currency, will quickly destabilize confidence in the banks holding this debt and may lead to a deposit run. Alternatively, a change in the exchange rate coupled with unhedged foreign exchange exposure in the corporate sector can undermine confidence in the banks that have lent to that sector. The run on the banking system can take the form of a withdrawal of cross-border lending by nonresident creditors, or the withdrawal of deposits by domestic residents.

Many of the characteristics of a capital account crisis derive from the adjustment in portfolios that follows from an initial shock. Underlying weaknesses in balance sheets can linger for years without triggering a crisis. For example, a currency mismatch can be masked so long as continued capital inflows support the exchange rate. Consequently, the exact timing of a crisis is difficult to predict. However, should a shock undermine confidence, it can trigger a large and disorderly adjustment, as the initial shock reveals additional weaknesses and a broad range of investors, including local residents, seek to reduce their exposure to the country. Massive flows are the necessary counterpart of a sudden move toward a new equilibrium of asset holdings stemming from rapid stock adjustments. If these flows cannot be financed out of reserves, the relative price of foreign 
and domestic assets has to adjust. An overshooting in asset prices (including the exchange rate) is likely, as investors rarely have access to perfect information and may be prone to herding.

\section{Policy Implications}

Information about sectoral balance sheets is most useful if it is available in time to allow policymakers to identify and correct weaknesses before they contribute to financial difficulties. In practice, however, balance sheet information is often only partly available and can be obtained only with significant time lags, which limits its utility for all but ex post analysis. Balance sheet analysis starts with in-depth analysis of sector vulnerabilities; the first step is to identify gaps in country data and to develop the sources needed to provide this data. There is an obvious case for better data collection and enhanced external disclosure of key balance sheet data.

The balance sheet approach also focuses attention on policies that can reduce sectoral vulnerabilities - particularly the vulnerability to changes in key financial variables. It reinforces the importance of (i) sound debt management by the public sector to minimize the risk that weaknesses in the public sector's balance sheet will be a source of financial difficulty and to preserve the public sector's capacity to cushion against shocks originating in the private sector; (ii) policies that create incentives for the private sector to limit its exposure to various balance sheet risks, particularly the explosive combination of currency and maturity risks created by short-term foreign currency denominated borrowing; and (iii) the need to maintain a sufficient cushion of reserves. Flexible exchanges rates can help to limit exposure to currency risk and encourage ongoing hedging as well as facilitating adjustment to external shocks. But the balance sheet approach also underscores some of the risks that can continue to arise in a floating exchange rate regime, particularly if the public sector is the source of the financial instruments that help the private sector hedge against currency risk. While the balance sheet approach directs attention to indicators of financial strength rather than more classic macroeconomic indicators, it in no way diminishes the importance of sound macroeconomic policies. Large debt stocks emerge from persistent flow imbalances (fiscal and current account deficits), and underlying macroeconomic weaknesses are often the reason why countries can borrow only in foreign currency or with short maturities.

Information about sectoral balance sheets can also help policymakers evaluate the trade-offs between different policy objectives that arise after sectoral problems have snowballed into a systemic threat to the financial and economic system.

- A government faces the trade-off between helping the private sector hedge the exchange rate exposure on its balance sheet by selling foreign exchange (or other forms of exchange rate insurance) and the risk that government itself will experience a rollover crisis. Indeed, selling reserves to defend an overvalued nominal exchange rate has often aggravated a maturity mismatch on the government's own balance sheet. 
- An assessment of the relative scale of maturity and currency mismatches on sectoral balance sheets can help policymakers weigh the trade-off between an interest rate defense and a nominal exchange rate adjustment. In practice, policymakers are unlikely to be able to either direct monetary policy solely at domestic macroeconomic conditions or to direct monetary policy solely at exchange rate stabilization: they will need to aim for the right balance between exchange rate adjustment and monetary tightening.

- $\quad$ There is obvious appeal in running a countercyclical fiscal policy to limit the fall in output associated with a crisis that originates in the private sector. The scope to do so will depend critically on the strength of the government's balance sheet and its ability to obtain the needed financing.

Finally, the balance sheet approach can help the official sector to assess the case for financial intervention, and to better understand the scale of official support needed. Not all sectoral financial crises in emerging market economies call out for official intervention. In many cases, problems in the private sector's balance sheet can and should be resolved by restructuring the private sector's liabilities without any government intervention or financing. In other cases, the national government will be able to use its own reserves and other elements of the strength of its own balance sheet to prevent a crisis in the private sector from spreading. Such intervention should be accompanied by steps to reinforce incentives for more prudent behavior in the future, including closing weak institutions. However, there are cases where the country's authorities will lack access to the resources - notably foreign exchange reserves - on the scale needed to act to prevent a crisis on private sector balance sheets (for example, a run on foreign currency denominated bank deposits) from snowballing. And the government cannot intervene when it is the source of financial distress itself.

Exceptional external financing from the official sector may be justified under some circumstances as part of a strategy to prevent a broader crisis. The genesis of recent financial crises points to the need to address sector balance sheet problems quickly and in a targeted manner, before they snowball into even larger problems that put severe pressure on a country's balance of payments and trigger a deep crisis that results in a large fall in output. In times of stress, a country may need to quickly increase its holdings of gross reserves to be in a position to support the orderly unwinding of balance sheet problems. Fund support can therefore play an important role in augmenting a country's reserves so that it is better positioned to contain the crisis.

The scale of the needed support can be quite large, as a country's financing needs will be proportionate to the stock of outstanding claims of the sector in distress. All foreign currency denominated debts - even if between residents - can generate pressure on official reserves. Claims denominated in domestic currency can also be a source of pressure, as there are limits to the extent monetary expansion can be used to address a domestic rollover crisis without ultimately putting pressure on reserves. 
Yet even as the balance sheet approach highlights the case for official support to avoid a crisis that snowballs across sectors and becomes a generalized loss of confidence, it also underscores the limits on what official intervention can be expected to accomplish. Borrowing from the official sector does not transform either the country's aggregate balance sheet or the government's balance sheet for the better. Increased access to foreign exchange in the short run is offset by a new liability to preferred creditors. External borrowing from official creditors may help address a sectoral maturity mismatch, including a rollover crisis stemming from a maturity mismatch on the government's own balance sheet. But official lending cannot resolve a country-wide currency mismatch. At best it can provide access to foreign exchange liquidity that allows the private sector to reduce its open foreign currency position - at the cost of increasing the government's foreign currency exposure. The accumulation of additional senior debt will certainly increase capital structure risk. Official lending can temporarily cover a maturity mismatch and therefore provide time to make appropriate adjustments - whether to the exchange rate regime or to the fiscal account - to strengthen the country or the government's long-term sustainability. But official lending itself will not make an unsustainable balance sheet sustainable. 


\section{INTRODUCTION}

This paper sets out a framework for understanding financial and currency crises in emerging market economies. The framework is based on a so-called "balance sheet approach", which has gained prominence in the academic literature (Box 1). This paper is not intended to lay out the beginning of an operational framework, nor are many of the insights presented here new. Rather, this paper seeks to lay out the balance sheet approach systematically and to pull together its various insights, with an emphasis on the policy choices that countries in crisis face and the case for external official financing. The data requirements needed for balance sheet analysis and the framework's implications for crisis prevention are discussed more briefly. These topics have been treated more thoroughly elsewhere, including in recent board papers on data provision and vulnerability analysis. ${ }^{2}$

Recent capital account crises have differed from earlier crises and balance of payments difficulties in several respects. First, financing needs erupted suddenly and on an unprecedented scale. Second, payments difficulties were not limited to transactions between the sovereign and nonresident investors, but often had their origins in the private sector, both financial and corporate, as well as in transactions between residents. Finally, the scale and pace of economic adjustment was sharp and dramatic, often driven by large capital outflows and substantial exchange rate adjustment. The analysis of these capital account crises and the ways in which financial difficulties are propagated across the different sectors of the economy, including spilling over into the external accounts, has been a major challenge to policy makers. ${ }^{3}$

The balance sheet approach represents a useful way of thinking about these problems. Beyond improving the understanding of the genesis of financial crises, it has implications for the Fund's approach to crisis prevention and resolution. First, it can further strengthen the framework for Fund surveillance, especially in emerging market economies. Indeed, the Fund's involvement in the development of data sources and its surveillance work is already increasingly focused on balance sheet vulnerabilities. Second, provided that the data are available, it can help to gauge ex ante the scale of potential sources of pressure on a country's reserves, and the financial problems that may develop if sufficient reserves are not available to meet these sources of pressure. Such analysis could help Fund staff make more

\footnotetext{
2 See International Monetary Fund (2002a, 2002b, 2002c); also Bussière and Mulder (1999); Johnston, Chai and Schumacher(2000); Gosh and Gosh (2002); Hemming, Kell and Schimmelpfennig (forthcoming).

${ }^{3}$ See, for example, Ortiz (2002).
} 


\section{Box 1. The Balance Sheet Approach in Recent Academic Literature}

Recent experience has led to a thorough rethinking of economists' views of the causes, genesis and resolution of currency and financial crises. Until the mid 1990s, the standard "first generation" model explained a currency crisis in macroeconomic terms, usually as a result of monetized fiscal deficits leading to reserve losses and eventually the abandonment of an exchange rate peg (Krugman (1979); Flood and Garber (1984)). This first generation literature also introduced additional factors that may help to explain the dynamics of a crisis, such as current account imbalances, real exchange rate misalignments, output effects of misalignments; effect on the debtservicing costs of the government when expected devaluation occurs and implications of borrowing to defend a peg. The stress, however, was on fundamental factors and on the idea that a crisis would be triggered more or less mechanically once reserves had reached a critical level. ${ }^{1}$

The ERM crisis of 1992 and, more importantly, the Mexican crisis of 1994-95 led to a "second generation" of crisis models. It was recognized that a crisis could be triggered by an endogenous policy response as the authorities decide whether to devalue based on tradeoff between the benefits and costs of floating. ${ }^{2}$ Moreover, these currency crises added the insight that, in addition to fundamental weaknesses (such as an overvalued currency and an unsustainable current account deficit), some elements of self-fulfilling panic can also be at work. In Mexico, as a large amount of short-term foreign currency linked debt (tesobonos) was coming to maturity and foreign reserves were insufficient to service this debt, the risk of a self-fulfilling rollover crisis driven by investors' panic became evident. These features were captured in so-called "second generation" models of currency crises (Obstfeld, 1994; Drazen-Masson (1994); Cole and Kehoe (1996)). The possibility of multiple equilibria contained in many of these models can be re-interpreted in the context of the balance sheet approach as a product of liquidity mismatches, either in the government sector or in the private sector. Such mismatches may lead to a self-fulfilling currency run or debt rollover crisis or banking run crisis. So, many second-generation models can be seen as stressing one element of balance sheet vulnerabilities.

The Asian crisis of 1997-98 confirmed the view that the private sector, rather than traditional first generation fiscal imbalances, could be at the core of a crisis. While the Asian crisis had some elements of a self-fulfilling "liquidity run" (see Sachs and Radelet (1998), Rodrik and Velasco (1999)) as in the case of the roll-off of the crossborder Korean interbank lines, this crisis brought to the open a number of additional vulnerabilities in the corporate and financial sector of these economies. The Asian crisis also highlighted that currency crises are often associated with banking crises ("twin crises") and that the currency crises of the 1990s were driven by sharp and unexpected movements of the capital account ("sudden stops" and "reversals of capital inflows") rather than traditional current account imbalances. A third generation of models, based on balance sheet analysis, was developed to understand how capital account movements drive currency and financial crises (see Dornbusch (2001)).

1/ Harry Johnson and others have long emphasized that changes in demand for money (a stock) would result in balance of payments flows in the context of a fixed exchange rate regime. A fall in demand for monetary assets would lead to a flow of reserves out of the country, while an increase in demand for monetary assets would require either capital inflows or current account surpluses to generate the needed stock of reserve assets. Recent work has tended to put less emphasis on changes in demand for money and more emphasis on shifts in demand for financial assets.

2/ For example, in the ERM (Exchange Rate Mechanism) crisis in 1992 some governments chose suddenly to devalue when the costs of an overvalued exchange rate in terms of growth and unemployment became too great. (continued) 


\section{Box 1 (concluded). The Balance Sheet Approach in Recent Academic Literature}

One strand of third generation models emphasizes that the balance sheet vulnerabilities are driven by microeconomic distortions. These include weakly supervised and regulated financial systems; connected and directed lending; moral hazard driven by implicit and explicit government guarantees leading to over borrowing and over lending and excessive current account deficits; fixed exchange rates distorting external borrowing in the direction of short-term foreign currency debt (see Krugman (1999), IMF (1998), Corsetti, Pesenti and Roubini (1999a, 1999b)).

Another strand of this literature has stressed the role of balance sheet imbalances deriving from currency mismatches (Krugman (1999), Cespedes, Chang and Velasco (1999), Gilchrist, Gertler and Natalucci (2000), Aghion, Bacchetta and Banerjee (2000), Cavallo, Kisselev, Perri and Roubini (2002)). This body of work stresses that large currency depreciation in the presence of foreign currency liabilities ("liability dollarization") can increase the real burden of debts denominated in foreign currencies and can trigger an investment and output contraction. In some of these models the currency crisis that leads to exchange rate movements and balance sheet effects is self-fulfilling. ${ }^{1}$ In other models, fundamental shocks (such as terms of trade shocks) trigger the need for a real depreciation that, in turn, prompts the adverse balance sheet effects. Some models compare the performance of fixed versus flexible exchange rate regimes in the presence of this liability dollarization. In others, even a real shock that requires a real depreciation triggers an overshooting of the real exchange rate (beyond what is warranted by fundamentals), thus exacerbating the balance sheet effects of foreign currency liabilities.

A third strand of the balance sheet literature is closer to "second generation" models in the emphasis on selffulfilling, "non-fundamental" runs. These models (for example Chang and Velasco (1999)) reinterpret the financial crises of the 1990s as international variants of "bank run" models (as Diamond and Dybvig (1983)). Again, an important balance sheet aspect of these international bank run models is that liquidity mismatches make governments and financial institutions in emerging markets vulnerable to partly self-fulfilling runs. One insight is that panics can be self-fulfilling because of the feedbacks between the depreciation of the currency and the deterioration of the banks' balance sheets in the bank or those who have borrowed from the bank have not hedged their currency exposure (see Jeanne and Wyplosz (2001), Burnside and others (1998), Schneider and Tornell (2000)). Thus, these models provide an explanation of the "twin crises". Another insight is that foreign currency liquidity provision from external official creditors (in some formalizations an international lender of last resort) may help to contain such liquidity runs. A final insight is that the risk of such runs is greater under fixed exchange rates, as both local currency and foreign currency liquid assets are potential claims on the limited liquid reserves of the central bank.

Other contributions try to model the "sudden stop" and "capital inflow reversal" phenomenon (Calvo (1998), Calvo and Mendoza (1999), Mendoza (2000), Schneider and Tornell (2000)). These models tend to be eclectic combinations of the above ideas (currency and liquidity mismatches, balance sheet effects, moral hazard distortions, "panicky" behavior of partially informed domestic and international investors leading to a "rush to the exits" and contagion, financial sector frictions, over investment in the non-tradable sectors) to explain the joint phenomenon, of sudden stops, credit crunches, currency crises and output contraction after a crisis.

Another strand of the literature draws explicitly on corporate finance theory in order to better explain the vulnerability of emerging markets to financial crises. Pettis (2001) emphasizes the importance of a country "capital structure" in determining a country's vulnerability to market volatility, and argues that emerging market economies have both underestimated volatility in financial markets and failed to manage their balance sheets to minimize their exposure to this volatility. He puts particular emphasis on "inverted" capital structures that magnify a shock: debt servicing costs increase as payments capacity decreases. The "macro-finance" approach (See Gray, 2002) similarly draws on corporate finance theory and particularly on "contingent claims analysis" to evaluate the robustness of country's financial systems and to help assess sovereign risk.

1/ An expected depreciation leads to a currency run and collapse of a peg. Then, the strong real depreciation wipes out the private sector's balance sheets (also determining their perceived ability to borrow) and ex post validates the loss of confidence and the currency crash. 
explicit the assumptions used to assess financing needs and the risks that the need may be larger or smaller than forecasted. Thirdly, the balance sheet approach can help to provide a theoretical underpinning for the Fund's macroeconomic policy advice during capital account crises, which may differ from that given in conventional current account-driven balance of payment difficulties. Finally, the balance sheet perspective helps to identify how external official lending in support of a country's adjustment policies can address various balance sheet mismatches, as well as the circumstances when the best strategy is the use of external official financing to support a debt restructuring. Note that the impact of a financial crisis in emerging economies on the balance sheets of its external creditors and investors - a potential mechanism for contagion-is not explored in this paper. Rather, the focus is on the impact of a financial crisis in one sector of an emerging market economy on the balance sheets of other sectors.

The rest of this paper is organized as follows. Section II introduces some general concepts underlying the balance sheet approach, and discusses how these apply to the experience in recent financial crises. It also identifies some characteristics of capital account crises, including the large and unpredictable size of financing gaps that emerged. (The Annexes show how the balance sheet approach could, in principle, be used to estimate prospective financing gaps.) Section III briefly sketches out how balance sheet analysis might help to sharpen the Fund's work on crisis prevention, and includes a discussion of the essential role of data availability in the operationalization of the balance sheet approach. It then concentrates on some of the policy trade-offs faced by countries experiencing capital account crises. Section IV focuses on the role of external official financing in addressing balance sheet vulnerabilities and particularly the gap between short-term foreign currency denominated debt and liquid reserve assets. It explores the justifications for external official financing during crises as well as the circumstances when debt restructuring may be necessary. It also notes some of the limits on the types of crises that can be addressed through official financing from a balance sheet point of view. While the balance sheet approach highlights the broad sets of claims that can generate crises and put pressure on reserves and the need to assess the scale of financing provided in relation to the stock of relevant claims, it also underscores the limits on the capacity of official financing to provide an effective solution to many balance sheet problem, and the risks inherent in meeting a large surge in demand for foreign currency liquidity with large-scale borrowing from official creditors. Section V presents conclusions.

\section{The Anatomy of Balance Sheet Crises}

\section{A. Balance Sheet Concepts: A Primer with Examples}

\section{A stylized economy can be viewed as a system of the balance sheets of all its} agents. Unlike the more traditional analysis of an economy that looks at the flows occurring over a defined period of time - such as the annual output, fiscal balance, current account balance or investment flows - a balance sheet analysis looks at stocks of assets and liabilities at a certain point in time - such as debt, foreign reserves, loans outstanding, inventory at the 
end of the year. Obviously, the two approaches are interrelated, as the difference in a stock variable at two dates is related to the flow in the period between them. ${ }^{4}$

As a first step, one may distinguish an economy's main sectoral balance sheets: the government sector (including the central bank), the private financial sector (mainly banks) and the non-financial sector (corporations and households). ${ }^{5}$ These sectors have claims on and liabilities to each other, and to external (non-resident) entities. When consolidating the sectoral balance sheets into the country's balance sheet, the assets and liabilities held between residents net out, leaving the country's external balance vis-à-vis the rest of the world (non-residents). ${ }^{6}$ Figure 1 shows a stylized system of such accounts, which excludes non financial assets and liabilities. ${ }^{7}$

Sectoral balance sheets provide important information that remains hidden in the consolidated country balance sheet. A country's balance sheet can show the potential scale of vulnerability to reversals in external financing flows, but it is often inadequate for examining the genesis of such reversals. Weaknesses in certain sectoral balance sheets may contribute to the creation of a countrywide balance of payments crisis, yet they may not appear in a country's aggregate balance sheet. An important example is foreign currency debt between residents, which is netted out of the country's aggregated balance sheet. Nevertheless, if the government is unable to roll over its hard currency debts to residents and must draw on its reserves to honor its debts, such debts can trigger an external balance of

\footnotetext{
${ }^{4}$ The change in stock is a combination of changes in valuation of the existing stock of assets and liabilities, and net additions to the stock from flows during the preceding period.

${ }^{5}$ For the purpose of the following analysis it is most important to distinguish assets that in event of a crisis are under control of the country authorities from those that are being controlled by the private sector. To simplify the presentation, the separation of the government and the central bank is therefore not highlighted. The distinction in monetary and fiscal authorities - part of the internationally accepted statistical guidelines - is of course important for many other purposes, not least to reflect the role of central bank independence and also the Fund's lending to country's monetary as opposed to its fiscal authorities. In general, the statistical format used here can be adjusted to that of the System of National Accounts 1993 - the sectorization of an economy having to be decided flexibly, taking into account country circumstances.

${ }^{6}$ In the official Balance of Payments Statistics the balance sheet of the stock of external financial assets and liabilities, broken down in four sectors, is referred to as the International Investment Position (see IMF's Balance of Payments Manual, $5^{\text {th }}$ edition, 1993).

${ }^{7}$ For this presentation see also Dixon, Haldane, and Hayes (2001).
} 
Figure 1. Financial Interlinkages Between the Sectors in an Economy

\begin{tabular}{|c|c|}
\hline \multicolumn{2}{|c|}{$\begin{array}{c}\text { Government sector } \\
\text { (incl. Monetary authorities) }\end{array}$} \\
\hline Assets & Liabilities \\
\hline $\begin{array}{l}\text { Financial claims on } \\
\text { Financial sector } \\
\text { Non-fin. priv. sector } \\
\text { Rest of the world }\end{array}$ & $\begin{array}{c}\text { Financial obligations to } \\
\text { Financial sector } \\
\text { Non-fin. priv. sector } \\
\text { Rest of the world } \\
\text { Net worth }\end{array}$ \\
\hline
\end{tabular}

Financial sector

(Banks and other financial institutions)

\begin{tabular}{c|c} 
Assets & Liabilities \\
\hline Financial claims on & Financial obligations to \\
Government sector & Government sector \\
Non-fin. priv. sector & Non-fin. priv. sector \\
Rest of the world & Rest of the world \\
& Net worth \\
\hline
\end{tabular}

\begin{tabular}{c|c}
\multicolumn{2}{c}{$\begin{array}{c}\text { Non-financial private sector } \\
\text { (Corporations and households) }\end{array}$} \\
Assets & Liabilities \\
\hline Financial claims on & Financial obligations to \\
Government sector & Government sector \\
Financial sector & Financial sector \\
Rest of the world & Rest of the world \\
& Net worth \\
\hline
\end{tabular}

\begin{tabular}{c|c}
\multicolumn{2}{c}{ Rest of the world } \\
Assets & Liabilities \\
\hline Financial claims on & Financial obligations to \\
Government sector & Government sector \\
Financial sector & Financial sector \\
Non-fin. priv. sector & Non-fin. priv. sector \\
& Net international \\
& investment position \\
\hline
\end{tabular}


payments crisis. The risk that difficulties rolling over domestic debts can spill over into a balance of payments crisis is particularly acute in a world where capital accounts have been liberalized. Such risks are augmented if difficulties in one sector can cascade into other healthy sectors as a result of financial interlinkages.

Four general types of risks are worth highlighting when assessing balance sheet weaknesses: maturity, currency, capital structure, and solvency. Maturity and currency mismatches create exposure to particular sources of risk, including market risks such as a change in interest rates or exchange rates, while capital structure mismatches reduce a country's ability to bear these as well as a range of other risks. ${ }^{8}$ All of these mismatches create vulnerabilities that can lead directly to solvency risk, although solvency risk can also arise from other sources. ${ }^{9}$ Analyzing these risk can help to shed light on the crises in Mexico (1994), Thailand (1997), Indonesia (1997), Korea (1997), Russia (1998), Brazil (1999), Turkey (2001), Argentina (2002), and Uruguay (2002). Brazil's recent financial difficulties are not explicitly covered in this paper since an assessment would be premature.

\section{Maturity mismatch risk}

Maturity mismatch risk arises typically when assets are long term and liabilities are short term. Maturity mismatches create rollover risk: the risk that maturing debts will not be refinanced, and the debtor will have to pay the obligation in cash. Maturity mismatches also create interest rate risk for the debtor: the risk that the level and/or structure of interest rates that the debtor has to pay on its outstanding stock will change. Interest rate risk can also arise if longer-maturity liabilities carry a floating interest rate, particularly one linked to the interest rate on short-term debt. ${ }^{10}$ Maturity mismatches can

${ }^{8}$ Pettis (2001) and others who are grounded in corporate finance use the term "capital structure" to refer to the maturity and currency composition of an entity's debts, as well as the debt to equity ratio. Because maturity and currency risk are of particular importance for countries, this paper isolates these sources of risk. The paper uses the term capital structure only to refer to the balance between debt and equity, not to the currency and maturity composition of debt.

${ }^{9}$ This is not an exhaustive list of the risks on a balance sheet. Moreover, there are other possible ways of breaking down various types of balance sheet risks than those discussed in this paper: for example, one could identify rollover risks, market risks (which would include both currency and interest rate risk), credit risk, operational risk and solvency risks. The categorization laid out here has the advantage of highlighting the underlying mismatches that create sources of vulnerability from a debtor's perspective.

${ }^{10}$ Creditors who hold long-term debt with a fixed interest rate are also exposed to the risk that an increase in the interest rate may reduce the market value of their debt. This is a particular concern for financial institutions which finance themselves with short-term debt (such as deposits) and hold longer-term assets. 
arise in either domestic or foreign currency. For example, a debtor may have short-term foreign currency debts that exceed his liquid foreign currency assets, even if his aggregate foreign currency debts match foreign currency assets.

Maturity mismatch risk was significant in all recent crisis episodes. Often the maturity mismatch in foreign currency led to a rollover crisis, as short-term foreign current debts exceeded liquid reserves. In some cases, pressures came through short-term government debt (Mexico, Russia, Turkey, and Argentina) while in others they arose from the short-term liabilities of the banking system (Korea, Thailand, Russia, Turkey, Brazil, Uruguay, and Argentina). In yet other cases (Russia, Turkey, Brazil, and Argentina) the interest rate on short-term government debt increased sharply in the period before the crisis, reflecting a higher perceived currency and country default risk, as well as worsening the debt dynamics of the government. In many of these episodes, the exposure of financial institutions to a change in interest rates was also a source of distress: banks' liabilities, as is typically the case, tended to be short term and their cost highly sensitive to spikes in shortterm interest rates, while their assets were relatively longer term (loans to households and corporations and investments in medium-long term government bonds) and often carried fixed interest rates.

\section{Currency mismatch risk}

Currency mismatch risk is caused by a disparity in the currencies in which assets and liabilities are denominated. Liabilities may be denominated in a foreign currency, while assets are denominated in domestic currency, leading to severe losses when there is a sharp change in the nominal and real value of the domestic currency. Currency mismatches generally are more pronounced in emerging economies than in advanced industrial economies. This is because emerging markets agents, public and private, are often unable to borrow in local currency from non-residents or even, in many cases, from residents. As a result, obtaining capital for investment often requires taking on currency risk. Attempts by one sector to hedge currency risk associated with such borrowing will just transfer the currency mismatch to other sectors within the country. For example, banks borrowing in dollars and then on-lending in dollars to corporations can technically reduce the currency risk on their books. But this increases the corporate sector's currency risk, and, if the firms borrowing in foreign currency are not large net exporters, the risk that the firms will be unable to pay the banks in the event of a devaluation (credit risk, see below). Moreover, currency mismatches can trigger shifts in capital flows that create pressure on reserves. ${ }^{11}$ The direct impact of a real depreciation on a net foreign currency debtor is an income or wealth effect, as the real size of the debtors' liabilities increase relative to its assets. Net foreign currency debtors often seek to protect themselves against further real depreciation by purchasing additional foreign currency assets, which is why a surge in

${ }^{11}$ For a good discussion of currency mismatches and deposit runs see Wyplosz and Jeanne (2001). 
demand for instruments that provide currency hedges is particularly common immediately before and immediately after the collapse of an exchange rate peg.

Almost all recent crisis episodes were marked by currency mismatch exposures. At the government level, currency mismatch risk was important in Mexico, Brazil, Turkey, Argentina and Russia (even if in some cases the government debt was only foreign currency-linked rather than directly foreign currency-denominated). Currency mismatches were large in the banking system in Korea, Thailand, Indonesia, Turkey, Russia, and Brazil (in early 1998). Currency mismatches were large in the nonfinancial private sector (corporations and households) in Korea, Thailand, Indonesia, Turkey, Argentina, and Brazil (before the private sector increased its holdings of foreign currency denominated assets in 1998) and probably also in Uruguay. In many of these countries, the inflexible exchange rate regime in place prior to the crisis seems to have contributed to the development of large currency mismatches.

\section{Capital structure mismatches}

\section{Capital structure mismatch risk results from relying excessively on debt} financing rather than equity. The absence of an "equity buffer" can lead to financial distress when a sector encounters a shock. While payments from equity are state contingent, with profits and dividends falling in bad times, debt-service payments generally remain unchanged in bad times. Excessive reliance on debt financing - including short-term debt that gives rise to a maturity as well as capital structure mismatch - can be the result of weak corporate governance or tax and regulatory distortions. ${ }^{12}$

The crises in Korea and Thailand are evidence of the risks of heavy reliance on debt financing. ${ }^{13}$ The Korean government had severely restricted FDI before 1997 , encouraging external capital inflows to take the form of debt. In Thailand the tax regime favored corporate debt over equity. The resulting debt to equity ratios in both countries were very high at the onset of the crisis. In addition, in the banking and financial sector, the capital structure imbalance took the form of undercapitalized banks and financial institutions. The banks in many crisis countries were highly leveraged and the ratio of capital to risk-adjusted assets were often well below Bank for International Settlements (BIS) international capital adequacy standards, and well below the levels needed in light of the true risk exposure of these financial institutions. Thus, when liquidity and currency shocks hit the balance sheets of financial institutions - whether from a fall in asset values, an upsurge in non-performing loans, losses on open currency positions, losses on the

\footnotetext{
${ }^{12}$ See Friedman, Johnson, and Milton (forthcoming).

${ }^{13}$ Other examples of countries deficient of foreign direct investment and equity are Russia and Turkey.
} 
portfolio of longer term government debt, a shrinkage in deposits from a domestic bank run, or a roll-off of cross border lines - the capital buffer to absorb them was very limited.

\section{Solvency risk}

Solvency risk arises when an entity's assets no longer covers its liabilities; in other words, the net worth is negative. Solvency risk is related to maturity, currency, and capital structure mismatches, which can all increase the risk that a negative shock will trigger insolvency. The concept of solvency is relatively straightforward for the private sector's balance sheets: the value of a private firm's assets - appropriately valued - need to exceed its liabilities. But it requires some further explanation for the government sector and the country as a whole. A government's greatest net asset is the ability to generate primary fiscal surpluses, that is, its ability to raise more revenue from taxes than it spends. It is solvent as long as the present discounted value of all future fiscal primary balances is greater than the current stock of net government debt. Similarly, a country as a whole is solvent as long as the present discounted value of all future balances in the non-interest current account is greater than the current stock of net external debt. Thus, when assessing solvency, government debt is often compared to flow figures such as GDP or revenues, and a country's debt is compared to GDP or exports. ${ }^{14}$

Solvency risk differed widely between countries affected by recent crises. In Mexico, Korea and Thailand the sovereign seemed clearly solvent (even if in each episode some significant macroeconomic or structural/financial weaknesses existed). In other cases, high ratios of debt to GDP and/or revenues signaled the risk of a government solvency crisis and default. Also, in many episodes (especially Russia and Argentina, but also to some extent in Turkey, Indonesia, and Brazil) strong real exchange rates prior to the crisis improved the government's debt-to-GDP ratio by reducing the value of the government's foreign currency debts - so long as the exchange rate remained stable. After the crisis struck, the combination of foreign currency (including indexed) debt and a real depreciation produced a sharp increase in the stock of government debt. In some cases, this shock was amplified by the large fiscal costs of recapitalizing domestic banks (and indirectly the distressed corporate system), adverse debt dynamics stemming from a sharp increase in real interest rates, and a fall in growth. External debt levels in relation to GDP were similarly affected by the impact of large real depreciations, which increased solvency risk and led to default in Russia and Argentina.

${ }^{14}$ For the Fund's analytical framework for assessing solvency and debt sustainability see $\operatorname{IMF}(2002 a)$. 


\begin{tabular}{|c|c|c|c|c|}
\hline \multicolumn{5}{|c|}{ Box 2. How Balance Sheet Risks Apply to Different Sectors } \\
\hline Risk Sector & Maturity Mismatch & $\begin{array}{l}\text { Currency } \\
\text { Mismatch }\end{array}$ & $\begin{array}{l}\text { Capital Structure } \\
\text { Mismatch }\end{array}$ & $\begin{array}{c}\text { Solvency } \\
\text { (Liabilities v. Assets) }\end{array}$ \\
\hline Government & $\begin{array}{l}\text { Government's short- } \\
\text { term hard currency } \\
\text { debt (domestic and } \\
\text { external) v. } \\
\text { government's liquid } \\
\text { assets (reserves)* } \\
\text { Short-term domestic } \\
\text { currency denominated } \\
\text { government debts v. } \\
\text { liquid domestic } \\
\text { currency assets of the } \\
\text { government } \\
\text { *not all central bank } \\
\text { reserves are available } \\
\text { for government debt } \\
\text { service; some may be } \\
\text { pledged to back } \\
\text { currency, lent to } \\
\text { banks, etc }\end{array}$ & $\begin{array}{l}\text { Government's debt } \\
\text { denominated in } \\
\text { foreign currency } \\
\text { (domestic and } \\
\text { external) v. } \\
\text { government's hard } \\
\text { currency assets } \\
\text { (reserves) }\end{array}$ & N/A & $\begin{array}{l}\text { Liabilities of } \\
\text { government and central } \\
\text { bank v. their assets. } \\
\text { Assets include } \\
\text { discounted value of } \\
\text { future primary surpluses } \\
\text { (including seignorage } \\
\text { revenue) and the } \\
\text { financial assets of the } \\
\text { government and central } \\
\text { bank, including } \\
\text { privatizable state owned } \\
\text { enterprises } \\
\text { Liabilities may include } \\
\text { implicit liabilities from } \\
\text { pension plans as well as } \\
\text { contingent liabilities } \\
\text { stemming from } \\
\text { government guarantees }\end{array}$ \\
\hline Banks & $\begin{array}{l}\text { Short-term hard } \\
\text { currency debts } \\
\text { (domestic and } \\
\text { external) v. banks' } \\
\text { liquid hard currency } \\
\text { assets (and ability to } \\
\text { borrow from central } \\
\text { bank) } \\
\text { Short-term domestic } \\
\text { currency debts (often } \\
\text { deposits) v. liquid } \\
\text { assets }\end{array}$ & $\begin{array}{l}\text { Difference between } \\
\text { foreign currency } \\
\text { assets (loans) v. } \\
\text { foreign currency } \\
\text { liabilities (deposits/ } \\
\text { interbank lines) }\end{array}$ & $\begin{array}{l}\text { Deposits to capital } \\
\text { ratio (closely related } \\
\text { to capital to assets } \\
\text { ratio) }\end{array}$ & $\begin{array}{l}\text { Bank liabilities v. bank } \\
\text { assets and capital }\end{array}$ \\
\hline Firms & $\begin{array}{l}\text { Short-term debts v. } \\
\text { firms' liquid assets }\end{array}$ & $\begin{array}{l}\text { Debts denominated in } \\
\text { foreign currency } \\
\text { (domestic and } \\
\text { external) v. hard } \\
\text { currency generating } \\
\text { assets. }\end{array}$ & Debt to equity ratio & $\begin{array}{l}\text { Firms liabilities v. } \\
\text { present value of firms' } \\
\text { assets }\end{array}$ \\
\hline Households & $\begin{array}{l}\text { Short-term debt v. } \\
\text { liquid household } \\
\text { assets }\end{array}$ & $\begin{array}{l}\text { Difference between } \\
\text { Foreign currency } \\
\text { assets (deposits) v. } \\
\text { foreign currency } \\
\text { liabilities (often } \\
\text { mortgages) }\end{array}$ & $\mathrm{N} / \mathrm{A}$ & $\begin{array}{l}\text { Liabilities v. future } \\
\text { earnings (on wages } \\
\text { and assets) }\end{array}$ \\
\hline
\end{tabular}




\begin{tabular}{|c|c|c|c|c|}
\hline \multicolumn{5}{|c|}{ Box 2 (concluded). How Balance Sheet Risks Apply to Different Sectors } \\
\hline Risk Sector & Maturity Mismatch & $\begin{array}{l}\text { Currency } \\
\text { Mismatch }\end{array}$ & $\begin{array}{l}\text { Capital Structure } \\
\text { Mismatch }\end{array}$ & $\begin{array}{c}\text { Solvency } \\
\text { (Liabilities v. Assets) }\end{array}$ \\
\hline Country as a whole & 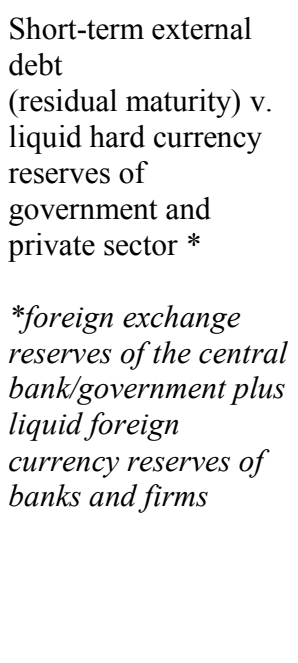 & $\begin{array}{l}\text { Net hard currency } \\
\text { denominated external } \\
\text { debt } \\
\text { *External debt } \\
\text { denominated in hard } \\
\text { currency minus } \\
\text { external assets } \\
\text { denominated in hard } \\
\text { currency }\end{array}$ & $\begin{array}{l}\text { Net external debt } \\
\text { stock (external debt } \\
\text { minus external assets) } \\
\text { relative to net stock of } \\
\text { FDI. } \\
\text { *Flow analogue: } \\
\text { Heavy current } \\
\text { dependence on debt } \\
\text { rather than FDI to } \\
\text { finance current } \\
\text { account deficit }\end{array}$ & $\begin{array}{l}\text { Stock of external debt } \\
\text { relative to both external } \\
\text { financial assets held by } \\
\text { residents and the } \\
\text { discounted value of } \\
\text { future trade surpluses, } \\
\text { (resources for future } \\
\text { external debt service)* } \\
\text { * A more complex } \\
\text { analysis would need to } \\
\text { include remittance of } \\
\text { profits on FDI as well. } \\
\text { While such remittances } \\
\text { are variable, they are } \\
\text { another claim on the } \\
\text { external earnings of the } \\
\text { country as a whole }\end{array}$ \\
\hline $\begin{array}{l}\text { Note that debts betw } \\
\text { debts are denominat } \\
\text { borrows foreign excl } \\
\text { currency asset on the }\end{array}$ & $\begin{array}{l}\text { sidents should appea } \\
\text { foreign currency, ca } \\
\text { from the household } \\
\text { ehold balance sheet }\end{array}$ & $\begin{array}{l}\text { the sectoral balance } \\
\text { a source of financia } \\
\text { or and lends foreign e } \\
\text { an equal foreign curre }\end{array}$ & $\begin{array}{l}\text { t. Debts between non-r } \\
\text { iculty. For example, if } \\
\text { nge to firms, this shou } \\
\text { liability on the balance }\end{array}$ & $\begin{array}{l}\text { idents, particularly if the } \\
\text { le banking system } \\
\text { appear as a foreign } \\
\text { heet of firms. }\end{array}$ \\
\hline
\end{tabular}

\section{Related risks}

These different types of risks are closely related and may all lead to credit risk, that is, the risk that a debtor will not be able to repay its debts. Solvency risk to the debtor is credit risk to its creditors. The banking system is particularly prone to credit risk, and, in turn, credit risk can be the trigger for a bank run. It is rational for depositors or other short-term domestic or external creditors to run to the exits if bank solvency is deteriorating. Thus, payment difficulties in one sector have the potential of quickly spreading to the economy as a whole if the sector's difficulties trigger a widespread bank run.

\section{B. Characteristics of Recent Capital Account Crises from a Balance Sheet Perspective}

\section{Pegged exchange rate regimes have played an important role in recent financial} crises. In each one of the capital account crises of the 1990s, the country maintained some form of exchange rate peg. The resulting expectations of nominal exchange rate stabilityperhaps combined with expectations of real appreciations of the domestic currency that would reduce the real cost of foreign currency borrowing - seem to have contributed to the accumulation of large currency mismatches. In contrast, countries with floating regimes are 
often better equipped to withstand external shocks. Not only can the exchange rate adjust to a shock, but the absence of expectations for stability in the nominal exchange rate limits incentives for the accumulation of excessive currency risk on sectoral balance sheets.

As sectoral balance sheet problems spilled over into other sectors, they grew larger ("snowballed"), with the banking sector often playing a crucial role in the transmission. Balance sheet crises have emerged from weaknesses in private sector balance sheets (banks and corporates) as well as weaknesses in the public sector's balance sheet. Such weaknesses could continue for some time without triggering a crisis. However, any shock that suddenly exposed the country's underlying vulnerability - a terms of trade shock, bad political or economic news, a growing recognition that debt levels are increasing more rapidly than income, a crisis elsewhere in the region - could cause a reversal of capital flows with associated pressure on reserves and the exchange rate. Currency depreciation in tandem with investors' panic then led to a mutually reinforcing mechanism that caused the snowballing. In the Asian countries, for example, a sharp deterioration in financial health of the corporate sector contributed to a sudden reversal of capital flows and an exchange rate shock. This in turn adversely affected the balance sheets of all other sectors with foreign exchange denominated debts. Thus, by the time the corporate balance sheet weakness was felt in the banking sector in the form of nonperforming loans, the scale of the problem was significantly larger than it had been initially. Hence, the problem not only cascaded from one sector to the other but grew in the process. In other cases, notably Russia, Turkey, and Argentina, the financial weakness of the sovereign triggered financial distress in domestic banks which held large amounts of the government's short-term obligations on their balance sheets. In all cases, a depreciation of the exchange rate weakened the asset side of the banks' balance sheets. Thus, banking and currency crises reinforced each other, even when the banking sector was formally matched with respect to currencies at the outset of the crisis.

Balance sheet difficulties, at both the sectoral and the country level, have shown the potential to develop into balance of payments crises. In some recent cases, where foreign investors cut their credit lines, liquid assets - both domestic and external — had to be drawn down to meet external debt payments. This, plus the unwinding of portfolio investment, put pressure on the exchange rate. The situation was often exacerbated by the lack of transparency and the herd behavior of investors, some of whom may have been ill informed about the specifics of the country. In other cases, the confidence of domestic investors was shattered: rather than invest in their home country, they suddenly sought to increase their holdings of external assets. This involved selling local assets or taking funds out of the local banking system and investing them abroad. Both put pressure on the country's reserves (in a fixed exchange rate regime) or on the exchange rate (in a floating regime). The increase in residents' desire to hold external assets required an increase in the economy's ability to generate the resources needed to purchase external assets, that is, a shift in the current account.

The private sector's balance sheet problems often ended up with the government. The liabilities created by implicit and explicit guarantees of the integrity of the 
banking system are an obvious example. By transferring the banking sector's difficulties onto the government's balance sheet in the event of an adverse shock, such contingent liabilities created a fiscal problem (Indonesia, Thailand) or exacerbated an existing one (Brazil, Turkey, Argentina). The resulting increase in the government's liabilities, in turn, often reduced domestic and external confidence in the government's solvency, and thus contributed to the snowballing mentioned above.

Sectoral balance sheet problems severely affected output levels. The wealth effect of balance sheet problems affected consumption and investment and, combined with credit crunches, led to sharply lower aggregate spending. Corporations' autonomous expenditure cuts - to restore financial health - coupled with a forced reduction of credit from banks in distress, exceeded the immediate positive impact on competitiveness associated with the exchange rate depreciations. As a consequence, initial output declines in several Asian crisis countries were much stronger than would have been predicted on the basis of underlying monetary and fiscal policies and the impact of the depreciation on the production of tradable goods. On the other hand, the sharp shift in trade balances ultimately allowed the quick rebuilding of reserves. In Mexico and Korea, for example, external demand pulled the economies out of recession fairly quickly and allowed a resumption of rapid growth without a return of underlying flow imbalances.

Assessing countries' external financing needs in these cases has been extremely difficult. In most crisis countries balance sheet information about the size and maturity of liabilities and assets of the banking and, especially, corporate sectors was incomplete or not available at all. Consequently, estimates about the looming financing needs remained highly uncertain. More comprehensive information on sectoral balance sheets would have helped in assessing the likelihood of a crisis, in managing crises when they did emerge, and in making more explicit the assumptions on which the estimates of financing needs were based (see Annex I). However, even if more detailed information on the maturity and currency composition of the stock of external liabilities is available, it still only gives an indication of the potential maximum financing need that could arise from the existing stock of external liabilities. Additional assumptions about the behavior of various creditors and investors, such as the willingness of foreign banks to roll over short-term debt, is needed to estimate likely net flows. Furthermore, the stock of liabilities can change quickly: if the central bank or government enters into new financial contracts to resist currency depreciation, the scale of claims on the country can increase rapidly. Thailand's sale of forward contracts (see Annex II) is an obvious example. Forecasting the extent of the real exchange rate adjustment presents another challenge and makes it extremely difficult to anticipate how large initial overshoots will affect the balance sheets of firms that have borrowed in foreign currency.

The demands for foreign exchange that eventually emerged were very large. The liquid foreign currency needs associated with the repayment of external debt in all the different sectors typically far exceeded the official foreign currency reserves. This gap was particularly acute when reserves were not effectively available because the monetary authorities themselves had large outstanding off-balance sheet obligations. As can be seen from Table 1, the gaps between short-term external debt and foreign reserves that emerged in 
recent capital account crises ranged from about 5 percent of GDP in Brazil to 35 percent of GDP in Indonesia. These measures do not even include the claims on the country's hard currency reserves that can arise from contracts among domestic residents denominated in foreign exchange. Alternative measures of potential foreign exchange demand, such as the deposit base including foreign currency deposits (M2) or even the sum of short-term external debt and the deposit base, underscore the scale of potential pressures on the exchange rate and reserves. Despite sizeable adjustments and, in some cases, contributions from the private sector through roll-over agreements or debt restructuring, this prompted unprecedented financial support packages from the official sector.

Table 1. Indicators of Potential Financing Needs in Recent Capital Account Crises (as percent of GDP)

\begin{tabular}{|c|c|c|c|c|}
\hline & Brazil (1998) & Indonesia (1997) & Korea (1997) & Thailand (1997) \\
\hline Short-term external debt ${ }^{1}$ & 10.5 & 42.7 & 12.4 & 31.3 \\
\hline Deposit base (M2) & 26.9 & 55.6 & 46.2 & 84.8 \\
\hline Gross foreign reserves ${ }^{2}$ & 5.4 & 7.7 & 1.9 & 5.5 \\
\hline \multicolumn{5}{|l|}{ Memorandum items: } \\
\hline $\begin{array}{l}\text { in percent of GDP } \\
\text { in percent of quota } \\
\text { in million of U.S.\$ }\end{array}$ & $\begin{array}{c}2.3 \\
600 \\
18,262\end{array}$ & $\begin{array}{c}4.4 \\
490 \\
10,083\end{array}$ & $\begin{array}{c}4.0 \\
1938 \\
20,990\end{array}$ & $\begin{array}{c}2.2 \\
505 \\
3,926\end{array}$ \\
\hline
\end{tabular}

${ }^{1}$ End-period stocks at residual maturity, original maturity for Korea.

${ }^{2}$ End-period stocks; only usable reserves for Korea; net of forwards and swaps for Thailand.

${ }^{3}$ U.S. dollar value of GDP for year prior to arrangement.

${ }^{4}$ Using quotas existing at the time of program approval (before recent increase in quotas).

\section{Implications for CRisis Prevention ANd Fund Policy AdVICE DURING CRISES}

Consideration of balance sheet effects has catalyzed a rethinking of some economic policy advice before and during financial crises. Traditional macroeconomic flow model insights still hold, but the balance sheet approach offers a complementary focus on the accumulated debt stocks in sectoral balance sheets (see Box 3). The balance sheet approach is thus a useful tool for considering some of the tradeoffs of different policy options, both for crisis prevention and resolution. 


\section{Box 3. Balance Sheet Approach and Flow Analysis}

Despite the balance sheet approach's focus on assets and liabilities, an analysis of flows remains important. First, stocks of debt are the result of cumulative flows of past deficits. Second, as explained below, solvency implies that the present discounted value of future flows - primary balances or trade balances - has to be large enough to service current stocks of debt and prevent an unsustainable debt dynamics. Third, in most capital account crises, current flow imbalances also play an important role in crisis dynamics. Indeed, difficulties in attracting the new inflows needed to finance a large flow deficit may lead to serious difficulties with the roll over or refinancing of the existing stock of short-term debt

The balance sheet approach has implications that differ from those of more traditional "flow" explanations of crises. First, adjustment in a balance sheet crisis is typically sharp and front-loaded, as the sudden change of stocks generates large flows consistent with a new equilibrium. Secondly, and associated with this, there is an overshooting of asset prices. Thirdly, the various balance sheet effects greatly affect aggregate supply and aggregate demand, with pronounced repercussions on output. Fourthly, the balance sheet approach captures the possibility of cascading effects from sector to sector, in part because contingent liabilities are triggered. Finally, there is the possibility of vicious circles involving asset prices, desired asset stocks, and the real sector.

\section{A. Crisis Prevention}

The balance sheet mismatches that lie at the heart of modern-day capital account crises do not arise by accident. A country with a strong balance sheet can borrow to sustain imports, and more broadly consumption and investment, in the face of a shock to its current income. However, persistent flow deficits eventually translate into stock problems. For example, financing a current account deficit by issuing external debt has an impact on the country's aggregate balance sheet. Similarly, fiscal deficits feed directly into the government's balance sheet. As it becomes more difficult to finance such flow imbalances, governments and other borrowers often take on more currency and maturity risk, further weakening their balance sheets.

In addition to developing the data sources necessary to monitor asset and liability positions, governments in emerging market economies can have a critical impact on the strength of their national balance sheets through the economic policies they adopt. A solid government balance sheet - which necessarily requires a history of prudent fiscal management as well as careful management of the outstanding stock - can contribute directly to the health of a country's aggregate balance sheet. The government's policy also can help to create incentives - or disincentives - for sound private sector balance sheets. To cite just two obvious examples: the choice of an exchange rate regime influences incentives for borrowing in foreign currency; and the quality and content of banking system regulation influences the quality of the financial sector's aggregate balance sheet. 


\section{Box 4. Data Availability as Prerequisite for Balance Sheet Analysis}

Reliable data on the assets and liabilities of sectoral as well as countries' aggregate balance sheets is essential for making the balance sheet approach operational. While Fund staff has long recognized the desirability of analyzing data on stocks as well as flows, a lack of relevant data in most countries has led to a focus on a few key stock positions in the public sector balance sheet, particularly gross debt, deposits in the financial system, and NIR. A more comprehensive balance sheet analysis, however, requires detailed information on the size, maturity and currency composition of the assets and liabilities in all sectoral balance sheets. This needs to include data on debt among residents.

\section{Many of the ongoing efforts in improving data provision to the Fund aim at} balance sheet data. Member countries have been encouraged

- to compile the International Investment Position (IIP) and conduct the Coordinated Portfolio Investment Survey (CPIS) in line with the fifth edition of the Balance of Payments Manual (BPM5),

- to move towards the preparation of the general government's balance sheet according to the new Government Finance Statistics Manual (GFSM 2001),

- $\quad$ and to present debt data consistent with the new External Debt Statistics Guide (Debt Guide). ${ }^{1}$

Together, this would not only provide a country's external assets and liabilities by sector, maturity and instrument, but also the foreign currency and interest rate sensitivity of public sector liabilities. Data on the maturity profile of all public and other external debt should facilitate the retrieval of the effective residual maturity of debt stocks. Once effectively in place, such data provision will significantly improve the Fund's capacity to use the balance sheet approach in surveillance work as well as in program design.

${ }^{1}$ SDDS subscribers have been required to disseminate end-2001 IIP data by end-June 2002. Also, the SDDS prescribed and encouraged categories for external debt have been adopted as a benchmark for surveillance. These categories will become mandatory for SDDS subscribers by end- March 2003. 
There is a growing consensus on the need for policies that can help to guard against balance sheet vulnerabilities.

- $\quad$ More flexible exchange rate regimes can provide considerable protection against the build-up of exposure to currency risks and help to adjust to external shocks.

- $\quad$ Countries should strengthen the public sector's balance sheet by aiming for balanced budgets and building up financial cushions (augmenting reserves). ${ }^{15}$

- Developing domestic markets for equity and local currency denominated long-term debt can help firms raise financing in ways that limit their financial vulnerability. This includes the development of markets for financial products that enable firms to hedge various risks. But at the same time, attention must be paid to the risks incurred by those who are supplying the hedging instruments.

- $\quad$ Sound public debt management can do much to limit an economy's overall vulnerability. Attention must be paid to short maturity structures, sensitivity to currency movements, and exposure to contingent liabilities.

- Domestic authorities and Fund surveillance need to pay greater attention to all debt structures that create potential for balance sheet shocks, including those in the private sector. The new External Debt Statistics Guide provides a useful conceptual basis for this. (See Annex I)

- Countries should limit contingent claims on the government's balance sheet, such as explicit and implicit guarantees.

- $\quad$ Transparency is critical, both at the micro and macro level. It contributes to market discipline and can help to discourage herd behavior. Requiring risks to be disclosed can also make it more difficult to take on excessive levels of risk. Specifically, it is essential to collect and disseminate data on the foreign exchange and the maturity exposures of the government, banks, and corporations.

- $\quad$ Particular attention should be paid to the country's aggregate external balance sheet. Compiling and disclosing the country's IIP, which provides information on the financial assets and liabilities — the financial balance sheet — of a country vis-à-vis the rest of the world, would be a good starting point for many countries.

- $\quad$ The resilience of capital markets and the financial system needs to be continually monitored. The Fund/Bank Financial Sector Assessment Program (FSAP) provides one means of assessing the strength of the financial sector, and its exposure to various "balance sheet" risks.

- Prudential regulation of the banks needs to take into account their direct, and indirect, exposure to foreign currency risk. It is not enough to match assets and liabilities. For

${ }^{15}$ At some level the incremental cost of additional reserves exceeds the marginal benefits. However, the series of recent "capital account" crises described here have created a case that for emerging market countries the benefits of holding higher levels of reserves than they did previously exceeds the opportunity cost. 
example, foreign exchange denominated loans to unhedged domestic corporates can leave the banking system vulnerable.

- Domestic tax or regulatory distortions that favor debt - particularly foreign currency denominated debt - over long-term equity should be avoided.

- $\quad$ Strong domestic insolvency (bankruptcy) regimes can help to facilitate an early restructuring of private debts, and thus avoid larger problems at a later stage.

- Improved analysis of possible balance sheet vulnerabilities to changes in sentiment and macroeconomic fundamentals such as exchange rates and interest rates can help to identify early on potential sources of vulnerability. Recent work on macroprudential (financial stability) indicators goes in this direction. ${ }^{16}$

Nonetheless, crisis prevention remains a difficult task. The remainder of this section looks at two particular issues noted above-government debt management and foreign currency denominated borrowing by private banks and firms (often called liability dollarization) — which pose particular challenges for emerging market economies that seek to increase the strength of their aggregate balance sheets.

\section{Public sector debt management}

Sound public debt management, while crucial for improving an economy's overall resilience, may pose a difficult challenge in practice. ${ }^{17}$ The public sectorincluding the central and regional governments - is often the country's largest external debtor and the public sector's domestic debt is often the largest single asset on the balance sheet of domestic financial intermediaries. Given that the government's key asset-its capacity to run future primary surpluses - is illiquid, long-term and typically a claim on domestic currency resources, in principle should be matched by long-term liabilities denominated in domestic currency. Yet, markets for long-term domestic currency denominated debt do not exist in many emerging market economies and realistically will take some time to develop in countries with a history of macroeconomic instability. In practice, many emerging markets must choose between longer-term borrowing denominated in foreign currency and shorter-term borrowing denominated in domestic currency. This may imply that such economies may not be able to sustain as high a debt level in relation to GDP as industrial countries. Limiting the level of debt may be the only way to maintain a resilient balance sheet if assets and liabilities cannot be matched. Sovereign borrowers should also try to avoid taking on both currency and maturity risk - that is, relying on shortterm foreign currency debt.

\footnotetext{
${ }^{16}$ See, for example, Mulder, Perelli and Rocha (2002); Evans et al. (2000).

${ }^{17}$ For the Fund's and World Bank's public debt management guidelines see IMF( 2001).
} 


\section{Foreign currency debt of the private sector}

Large currency mismatches in the private sector's aggregate balance sheet create significant risks. Two risks stand out in particular: the risk of a sudden withdrawal of foreign currency denominated deposits, and the risk that the financial sector will bedirectly or indirectly - exposed to a currency shock from a real depreciation. Requiring that financial institutions match foreign currency assets and liabilities and limit the size of net open positions in relation to capital may not be enough to eliminate these risks. Even if the size of the open currency position is limited, the banking sector's foreign currency assets may be illiquid and unavailable in the event of a run. Maturity mismatches in foreign currency will therefore continue to be particularly dangerous given the limits on the ability of the authorities to act as a lender of last resort in foreign currencies. Heavily dollarized banking systems also may pass currency risk on to their borrowers-either the corporate sector, the household sector, or the government. Indeed, simply requiring that the banking sector matches the currency composition of its assets and liabilities may, ironically, contribute to the creation of excessive foreign currency risk on corporate balance sheets. In liability-dollarized economies with a limited export base, there may not be enough exporters with natural hedges to insulate the financial sector as a whole against the balance sheet impact of a real devaluation. ${ }^{18}$

Although the move toward more flexible exchange rate regimes should help to discourage foreign currency denominated borrowing, it may not be sufficient to end liability dollarization altogether. Foreign currency borrowing is not simply a product of the illusion of nominal exchange rate stability provided by a relatively fixed exchange rate. Foreign and domestic investors in emerging markets are often simply not willing to take local currency exposure. Thus, floating will not eliminate - and may indeed sometimes increase - demand for financial instruments that offer hedges against the risk of real depreciation. ${ }^{19}$ Governments also may be reluctant to allow the exchange rate to adjust flexibly in the face of external shocks if the balance sheet impacts of real exchange rate movements are perceived to be too large.

Prudential regulation has been considered as an additional means to limit foreign currency exposure of the private sector. A range of measures could be used to discourage foreign currency denominated bank deposits and short-term, foreign currency

\footnotetext{
${ }^{18}$ To improve the balance sheet of the financial sector and the country as a whole, nonresidents must provide the needed hedge.

${ }^{19}$ Residents may prefer to keep bank deposits in foreign currency or prefer to hold domestic debt denominated in hard currency. These preferences may change over time. Governments may be tempted to increase the supply of foreign currency debt in times of financial turmoil in the hope that increasing the supply of hedging instruments will limit pressure on the currency and substitute for tightening monetary policy or selling reserves.
} 
denominated interbank borrowing. For example, higher reserve requirements for foreign currency denominated liabilities would both lower the return on foreign currency deposits relative to local currency denominated deposits, and force the banks to hold more liquid assets. This would contribute to creating a better liquidity buffer in the banking system. Policies that discourage short-term external borrowing by firms as well as banks - such as Chile's encaje (a reserve requirement that penalizes short-term external borrowing and short-term portfolio flows more heavily than long-term borrowing and direct investment)may warrant consideration in some circumstances. Yet, as with other types of capital controls, the difficulties in effectively implementing such measures should not be underestimated.

\section{B. Policy Advice and Program Design in Crises}

This section highlights how the balance sheet approach can help clarify policy choices once a financial crisis has erupted. This is done by way of examples that describe the use of familiar policy instruments. In addition to addressing specific macroeconomic and structural problems, all of these policies need to reestablish confidence-for example, in the integrity of the banking system and currency regime - in order to avoid a deeper crisis. In practice, it is often difficult to establish a priori of what is exactly required to reassure investors.

\section{Example 1. Exchange rate policy}

An overvaluation of the real exchange rate is usually best addressed by a depreciation of the nominal exchange rate. In principle, a needed adjustment can be achieved through either a nominal devaluation or a decline in domestic prices (deflation); both will ultimately result in an increase in the real burden of foreign currency-denominated debts. Of these, a nominal devaluation addresses the underlying overvaluation quickly, although not painlessly. If, however, there is a large currency mismatch, balance sheet analysis highlights a theoretical case for choosing deflationary policies as an alternative. Such a policy of sustained tight macroeconomic policies has two potential advantages. First, it avoids the risk that exchange rate overshooting will lead to the adverse and excessive balance sheet effects described above. Second, the relatively slower pace of adjustment may give firms more time to adjust and to rearrange their balance sheets. But achieving real adjustment through a reduction in nominal wages and prices requires, inter alia, a very flexible labor market - a condition that is met in only few countries. In most cases, downward adjustment in nominal prices and wages is slow, politically difficult, painful and leads to a reduction in real growth (as evidenced by Argentina's difficulties in implementing such austerity policies within the constraints of its currency board). And in cases where fiscal sustainability is in doubt, deflation may contribute to adverse public debt dynamics, both directly through higher real interest rates and through a lower rate of growth.

Governments should generally hesitate to use their reserves to defend a currency peg that comes under sustained pressure. Governments are often tempted to use their reserves to try to defend an exchange rate peg. The sale of reserves can help to maintain the 
peg and thus avoid the balance sheet impacts of a real depreciation without the compression in domestic demand that would result from an interest rate defense of the exchange rate. However, running down reserves creates another kind of balance sheet risk: a maturity mismatch between the government's short-term foreign currency liabilities and liquid foreign currency denominated assets. The balance sheet approach highlights this policy trade-off to policy makers: using reserves to defend a peg may help the private sector strengthen its balance sheets, but it implies increasing the maturity and currency risk on the government's own balance sheet.

- The sale of reserves increases the government's maturity mismatch in foreign currency, as the government loses the key liquid asset on its balance sheet.

Consequently, intervening in the foreign currency market may result in a run on the short-term foreign-currency denominated debt of the government or liabilities of the financial sector. For example, in 1994 Mexico sold off its reserves to defend its currency. This, however, left it vulnerable to a roll-over crisis, particularly because it had also increased its issuance of short-term dollar linked debt (Tesobonos), and such debt far exceeded remaining reserves.

- $\quad$ The sustainability of the government's own balance sheet may be put in peril as its currency mismatch increases. If a devaluation does eventually occur, the real value of net government debt will increase sharply.

- $\quad$ Transferring currency risk to the government risks creating expectations of government intervention that will encourage the taking of currency risk in the future.

- In practice, exchange rate defenses by the sale of reserves, especially over extended periods, have had mixed success.

Only where the level of official reserves is very high can reserves sensibly be employed ex ante to minimize the eventual balance sheet effects of any adjustment in the nominal and real exchange rate. In the context of a carefully designed monetary program, selling foreign exchange from the government's reserves to help meet a surge in demand for foreign exchange-including surges in demand in the context of a floating exchange rate regime - can have two advantages.

- There is an immediate positive impact on private sector balance sheets if the foreign exchange has been purchased by residents who reduce their open foreign exchange positions. Strengthening private sector balance sheets can potentially limit exchange rate overshooting by reducing the sudden, often panic-induced, demand for foreign exchange that follows the abandoning of a peg. Firms and banks that have hedged their exposure prior to a devaluation do not need to enter the market to cover open currency positions during market turmoil.

- Transferring currency risk to the government sector can, in some cases, help to avoid massive bank and corporate bankruptcies, and the resulting economic disruption. 
Bank and corporate failures often also result in contingent liabilities for the government, and lead to an increase in the net public debt. This has to be balanced against the risk that an increase in the government's currency mismatch prior to a real depreciation will also result in an increase in the net public debt as a share of GDP.

While the benefits of intervention are greatest if the intervention primarily helps residents hedge existing liabilities, intervention also facilitates the taking of short positions by residents and non-residents alike against the government. It is impossible to supply hedges only to those with existing mismatches and it is hard to know ex ante the scale of the preexisting currency mismatch in the private sector. Hence, governments face a tradeoff between weakening their own balance sheet and strengthening private balance sheets.

\section{Example 2. Monetary policy and foreign exchange intervention after a Devaluation}

Balance sheet considerations can help policy makers choose between defending the exchange rate and pursuing a counter-cyclical monetary loosening. Temporarily tightening monetary policy through raising interest rates can help to prevent excessive real depreciation, which can have a devastating impact on real debt levels if a sector has a large currency mismatch. But at the same time, a sustained increase in real interest rates can have devastating effects on sectors with a maturity mismatch, including banks and the government itself. The impact of higher interest rates on these sectors can, in turn, increase the risk of exchange rate overshooting. Thus, each of the alternatives, letting the exchange rate adjust freely or raising interest rates, may eventually lead to substantial output losses.

\section{Policymakers can only make informed decisions about such trade-offs if they} have at their disposal accurate sectoral balance sheet information. If the stock of shortterm debt is large, tight monetary policy will both depress economic activity and increase the real burden of the domestic debt stock. If, on the other hand, the scale of the open currency positions is large, reducing the risk of a larger move in the exchange rate by allowing a rise of short-term interest rates may be the right answer. Where both problems exist, the choice is particularly difficult, not least because sectors would be affected differently, depending on their exposure. This highlights the need for building up an appropriate data base, as discussed in Annex I. In practice, policy makers will need to find the right mix of policies to address both concerns. They are unlikely to opt either for monetary expansion irregardless of the impact on the exchange rate or tighten to defend the exchange rate irregardless of the impact of the real economy. Rather, they will aim for a monetary policy that avoids excessive depreciation, yet not tighten so much as to seek to avoid any exchange rate adjustment. Access to emergency external financing provides one way to ease the trade off between domestic and external stabilization, as it provides policy makers with an additional policy tool to help manage this dilemma. This is discussed further in the next chapter. 


\section{Example 3. Capital outflow controls}

Restrictions on capital outflows might be considered as a policy alternative to prevent an overshooting of the exchange rate without the need for a sharp monetary contraction. ${ }^{20}$ Capital outflow controls can in theory help to overcome the conflict between exchange rate stabilization and domestic macroeconomic stabilization by making low interest rates compatible with a more appreciated exchange rate (Krugman, 1998). The interruption of cross-border movements of capital may help avoid the negative balance sheet effects from a depreciated exchange rate on the one hand or very high interest rates on the other.

\section{Capital controls have also been suggested in the particular context of} comprehensive debt restructurings. Here, in addition to the potential benefit in helping to prevent the exchange rate from overshooting in the likely panic following the announcement of a debt restructuring, the controls can help to enforce a suspension of private external debt payments. In principle, such a suspension can reduce pressure on the foreign exchange market, as private debtors do not have to enter the market to purchase foreign exchange to make payments, and force private creditors to approach their debtors to initiate restructuring negotiations. Also, a "curfew on capital flight" can prevent official monies extended as emergency financing from financing capital flows, albeit for a limited period of time.

While in theory capital controls can provide some breathing space in the heat of a crisis, in practice, they come with a number of well-known costs. The enforcement of such controls requires a significant effort, and may be difficult even then if there is no welldeveloped administrative infrastructure in place. There is a risk that controls will be used as a substitute for sound macroeconomic policies or to defend an overvalued exchange rate. They can also create a culture of rent-seeking (for exemptions) and evasion that is detrimental to economic activity. Over time, the controls tend to loose their effectiveness, as loopholes are found to circumvent them.

An evaluation of the usefulness of capital controls in the recent financial crises is difficult, because of the very different circumstances under which they have been used. Thailand only made a brief attempt to fight speculation against the baht by imposing capital controls before finally adopting a floating exchange rate regime. Malaysia introduced selective capital controls, but only at a later stage in its crisis, after the ringgit had already depreciated substantially and in the context of less acute balance sheet problems and relatively strong macroeconomic policies. Russia was an example where capital and exchange controls were not primarily intended to add monetary policy freedom, but rather

${ }^{20}$ Restrictions on capital outflows do not require Fund approval under the Articles of Agreement, unless the outflows are deemed to be "payments for current transactions" within the scope of Article XXX, $(d)$. 
to prevent capital flight after the announcement of default and devaluation. Similarly, Argentina more recently introduced capital controls in combination with a freeze on bank deposits when exiting from its currency board arrangement and suspending payments on its sovereign debt.

\section{Example 4. Fiscal policy}

There is a case for using fiscal policy to offset the balance sheet impacts of a currency crisis. This is particularly true if currency mismatches were pronounced on private sector balance sheets prior to the currency crisis. In such a case, a real depreciation will increase the real debt burden of private agents. The resulting financial distress will reduce private investment - as some firms will be weakened and unable to borrow and others will be forced into bankruptcy. Higher levels of unemployment along with the financial distress will often lead to lower levels of consumption. Countercyclical government spending could help sustain aggregate demand while the private sector adjusts to a higher real debt burden following a currency crisis.

The scope for running a countercyclical fiscal policy to limit a fall in output during a crisis varies substantially across countries. It will generally depend on: (i) the availability of financing, including from official sources, (ii) the pre-crisis fiscal position of the government, including its accumulated debt stock, and (iii) the fiscal costs of supporting the financial system. In cases where weaknesses in the public sector's balance sheet (fiscal deficits, maturity and currency mismatches, contingent liabilities) lie at the heart of the crisis, limiting the government's borrowing to help avoid a sovereign debt crisis will need to take precedence over aggregate demand management. If the initial imbalances reside in the private sector and public debt sustainability is no reason for concern, as in Thailand and Korea, fiscal loosening can potentially contribute to macroeconomic stabilization.

\section{The Role OF OfFicial External Financing}

This section investigates whether the balance sheet approach can help determine when official external financing is justified. As pointed out in the previous chapters, addressing balance sheet needs before they snowball throughout the economy can help avoid a broader financial and economic crisis. If a generalized loss of confidence can be prevented, a surge of demand for external assets and an even larger financing need - a need so large that it may well be beyond the capacity of the official sector to meet - can be averted. The official sector's invention in Mexico in the winter of 1994/95, for example, helped to prevent a government rollover crisis from generating a complete loss of confidence in the domestic banking system and an even deeper crisis. It is important to recognize, however, that arguing that the need for reserves should be assessed relative to the outstanding stock of claims that can generate a financial crisis does not imply that the right policy response to always provide access to large scale official financing to meet a potential large financing need. Not all sector-level financing difficulties lead to external financing crises and many sectoral needs can be addressed either by a sector-specific debt 
restructuring or by the national authorities without external official support. The balance sheet difficulties of Japan's banking sector are a case in point.

While previous chapters discussed the full gamut of potential balance sheet difficulties, this chapter focuses on a more narrow set of balance sheet problems, and the role of external official financing in support of policy adjustment to address them. These almost always involve the overlap of a currency and a maturity mismatch. The clearest example is the difficulty that a sector - be it the government (Mexico in 1994/95), the banking sector (Korea in 1997/98), or the corporate sector (Indonesia in 1997/98) — can have rolling over its short-term foreign currency denominated debt.

Two key themes of this chapter are worth highlighting upfront: the broadening of the sources that can create pressures on official reserves and the importance of the timing as well as the scale of official support.

- $\quad$ Reserves are a financial as well as monetary asset. In addition to backing - explicitly or implicitly - the currency in circulation, reserves are also drawn on to provide emergency liquidity to meet payment needs. Increasingly, the "financial" demands for foreign exchange include payments difficulties that result from sectoral maturity and currency mismatches among residents - such as the inability of the government to roll over debts to the banking system.

- Making financing available at the early stages of a crisis, before difficulties in one sector have snowballed into a broad crisis, can be decisive. Holding reserves to finance prompt intervention can be vital in this context-and one important source of reserves is emergency financing from the external official sector.

\section{A. The Need for External Financing}

With deeper financial integration, the risk of sectoral problems generating a balance of payments crisis has increased. As discussed in Chapter II, difficulties by any sector in rolling over existing external debts can generate a crisis in the country's balance of payments. The potential for financial difficulty and ultimately a balance of payments crisis, however, is not limited to difficulties that arise from external debts, that is, claims of nonresidents. The growing linkages between the domestic financial markets and global financial markets make domestic and foreign assets close substitutes. A reduction in the willingness of a country's residents to hold foreign or domestic currency denominated claims on the domestic financial sector or on the national government is often accompanied by a desire to increase holdings of assets abroad. Hence, financial difficulties that arise as a result of mismatches on domestic sectoral balance sheets can give rise to external financial crises.

Balance sheet weaknesses in individual private firms generally carry limited risk of spilling over into a broader crisis. Firms (including private financial institutions) in distress will usually be able to make needed adjustments, and the balance sheets of their 
creditors should be strong enough to absorb any necessary restructuring of obligations. ${ }^{21}$ The resilience of the balance sheets of a distressed firm's creditors thus constitutes the first line of defense against a broader financial crisis. If, for example, a maturity mismatch leads a firm to run out of cash, either an out-of-court financial reorganization or a Chapter 11-type reorganization would allow the debtor and creditors to work through the resulting difficulties.

There are cases, however, when the resolution of private sector crises may warrant intervention by the national government in order to avoid spillovers to the broader economy. This is particularly true if the crisis either originates in the financial sector or has a clear risk of spilling over into the financial sector. In many cases, the national authorities will have the means to finance intervention to help avoid spillovers arising from sectoral balance sheet difficulties. The government can issue additional debt, tap its stock of assets (including official reserves), or, if necessary, print local currency. In such instances, the government uses the strength of its own balance sheet to limit the fallout of another sector's balance sheet weaknesses on the broader economy. In general, support should be concentrated on those banks or firms that are structurally sound (the classic role of the lender of last resort) and unsound institutions should be restructured or closed immediately. A difficult triage is often necessary to assess which institutions should be intervened, merged or even liquidated; and which ones are fundamentally sound and deserve some conditional financial support. Such financing is often associated with domestic adjustment: the government may need to make policy changes to strengthen incentives for sound financial management in the private sector, and to strengthen its own balance sheet to absorb any fiscal costs associated with its intervention.

Financial difficulties of the government itself carry high risk of generating a broader crisis. As discussed above, the government's debt is often a key financial asset held by the banking system. This interlinkage increases the risk that a government financing crisis will snowball into a banking crisis. A government in trouble may in the first instance seek financing from the domestic private sector, both through its ability to levy taxes and its ability to alter financial regulation to encourage domestic holdings of government debt. This, however, puts the integrity of the domestic financial system further at risk should the government's difficulties deepen.

${ }^{21}$ In practice there are cases where the government has committed itself to supporting private sector entities in distress, regardless of their ability to resolve the balance sheet problem on their own. This includes various forms of guarantees (including deposit insurance schemes) and commitments by institutions where the government has an equity stake. 


\section{B. The Case for Official External Financing or Official Support for a Debt Restructuring}

A government may consider seeking exceptional external financing if it is reaching the limits of its capacity to draw on its own reserve assets and to borrow in foreign currency on private markets on terms consistent with medium-term sustainability. In principle, an external financing need can be met by some combination of domestic policy adjustment, official support and private external financing, including through a restructuring of external claims. However, adjustment alone- even if its scale is large - is unlikely to be able to provide the resources required to cover the sudden surge in outflows that can arise in a capital account crisis. In fact, such drastic action may exacerbate other economic problems. For example, a deep contraction can aggravate domestic credit risk. Moreover, it may not be possible to resolve the fundamental trade-offs between domestic and external balance, such as the exchange rate/interest rate dilemma discussed in the previous chapter, without an additional policy lever such as access to external finance or a debt restructuring.

The Fund has a central role to play in providing official external financing to countries in financial crises. There are demands for foreign currency liquidity that cannot be met by adjustment alone and there are cases where the debt restructuring required to reduce the financing need cannot easily be absorbed by the balance sheets of a sector's creditors without risking a broader crisis. Indeed, addressing such balance sheet problems directly before such a scenario unfolds, may help to forestall a larger capital outflow, more adjustment in the balance of payments and a greater loss of national prosperity. The capacity to disburse large amounts of foreign exchange quickly — and the capacity to distinguish crises that can be effectively addressed by preferred lending from those that cannot - can be crucial to effective crisis resolution. Of course, early intervention also carries risks: if the program supported by official lending fails to stem the sectoral crisis and a broader crisis follows, the country will face an increased debt service to preferred creditors at a time when, as a result of the crisis, the demand for foreign exchange will have increased (and a large exchange rate adjustment may have taken place).

There are circumstances when the Fund could strengthen the monetary authorities' balance sheet so that, in turn, they are put in a better position to meet certain sector level financing needs, particularly for foreign currency liquidity. Helping the monetary authority to extend assistance to other sectors-the government as well as the private sector-without undermining its own balance sheet is consistent with the Fund's mandate. A reduction in demand for domestic assets-whether in domestic or foreign currency — often results in an increase in demand for external assets, and thus puts pressure on the balance of payments and, at a minimum, constitutes a drain on the country's foreign exchange reserves. ${ }^{22}$ In many cases, a country's monetary authorities

${ }^{22}$ Under Article V, Section 3(b)(ii), a member using Fund resources must represent that it has a balance of payments need because of: (i) a balance of payments deficit; (ii) an 
will be called upon to support sectoral balance sheets, and the authorities may approach the Fund for support. For example, in Turkey in 2001, the Fund's resources were used to help the central bank maintain an adequate external reserve cushion at a time when the monetary authorities were lending to the government to meet its fiscal needs on terms consistent with medium-term fiscal sustainability. The central bank's sale of foreign currency indirectly helped to strengthen the commercial banks' balance sheets. It increased the supply of foreign exchange, and thereby made it easier for the commercial banks to purchase the foreign currency needed to pay down their maturing foreign currency liabilities. Of course, it may not be prudent for the Fund and other official lenders to provide the scale of financing that the authorities need to address all sectoral balance sheet difficulties. NIR floors can be set accordingly to limit the authorities freedom of action. In some cases, the NIR floors will effectively require that the member adjust more to increase the supply of foreign exchange, seek some form of debt restructuring to reduce demand for foreign exchange, or-most likely_a combination of the two.

As mentioned in previous chapters (and shown in detail for Thailand 1996/97 in Annex II), if there is a large stock of hard currency denominated short-term debt that may not be rolled over, potential financing needs can be extremely large. If pressures emerge in such a situation, the official sector will have to make a difficult choice between four different approaches to providing the needed financing: (i) provide financing on a scale sufficient to cover at least a large fraction of the potential financing need; (ii) provide a more limited amount of financing in the hope that this financing, along with the policy adjustments, will reassure the country's creditors and thus catalyze the provision of the additional financing needed, (iii) seek a commitment for the private sector to roll over claims and extend maturities rather than an outright debt reduction, or (iv) condition official financing on concerted efforts to restructure the country's external liabilities or limit capital outflows. $^{23}$ Intermediate approaches to involving the private sector-those lying between catalytic and concerted techniques - have, however, proven increasingly elusive. Voluntary approaches can be very expensive, as the creditors will demand a high spread during a crisis to compensate for the risk of holding longer-term claims. But any non-voluntary restructuring of debts with some private sector creditors bears the risk of shattering market confidence, which in turn may trigger sudden balance sheet adjustments of the kind discussed earlier.

While official external support and debt restructuring may appear as substitutes, in some cases the two can be complementary. The case for combining

inadequate reserve position; or (iii) certain "developments in its reserves". The Fund's resources cannot be drawn to meet a potential balance of payments need, they must be drawn to meet an actual need and cannot exceed that need.

${ }^{23}$ A restructuring of existing claims of the external official sector (Paris Club) is understood here as a form of official financing. 
official financing and debt restructuring can be seen if one disaggregates debts at the sectoral level. If one sector has deep financial difficulties while other sectors and the country as a whole are in a sustainable position, it may make sense to restructure the debts of the sector at the heart of the crisis, while relying on official support to meet the balance sheet needs of other sectors. In other cases, a comprehensive restructuring to reduce the country's aggregate external debts may be necessary to restore sustainability. In this context, official external financing can help to meet emergency financing needs.

The balance sheet approach can help to assess potential sources of demand for foreign currency liquidity. An examination of sectoral balance sheets can help to gauge the potential demand for foreign exchange that could arise from the existing debts of residents and to specify with more precision the assumptions about rollover rates that underlie the calculation of the expected financing need. To the extent that balance sheet needs require monetary authorities to hold a higher level of gross reserves, they could be a factor in determining the size of member countries' access to Fund resources. The need for higher gross reserves associated with sector balance sheet weaknesses could provide a yardstick to help the official sector gauge the scale of the country's external financing need - a need which will necessarily depend on various assumptions about market behavior, such as rollover ratios. Determining the scale of need would be the first step in determining the right amount of access to Fund resources. The annexes discuss in more depth the substantial problems with operationalizing this approach.

The calculation of financing needs should not, however, prejudge the appropriate size of Fund support. The balance sheet approach can help inform judgments about the scale of Fund support needed to address a given need, but it does not provide a mechanistic means of identifying either the scale of need or whether a given need is best addressed through a debt restructuring or official lending.

However the balance sheet approach can provide a series of tests that can help policymakers judge the strength of the case for external official financing. The case for official financing is strongest:

- If the identified balance sheet problem giving rise to the need cannot be remedied with domestic resources and policy adjustment alone.

- If official financing can help to address the relevant balance sheet imbalance. Specifically, financing is needed to cover a maturity mismatch temporarily or, more controversially, financing can help to transfer currency risk from a sector with a weak balance sheet to a sector with a stronger balance sheet.

- If the financial position of both the country and the government are sustainable under reasonable assumptions with appropriate policy adjustments.

The last two "tests" are discussed in more detail below. Of course, the risk of generating moral hazard is an additional constraint on the availability of official resources. However, 
the balance sheet approach neither offers new insights into this debate nor a new way of framing the basic issues, so it is not discussed in depth here.

\section{Limits on Use of External Official Financing to Address Balance Sheet Needs}

Official financing is best suited to addressing financing needs arising from maturity mismatches, both at the sectoral level and for the country as a whole. There are two potential types of maturity mismatches worth considering.

- $\quad$ First, the private sector or the government can have difficulty rolling over its existing stock of foreign currency debts. This may be true for both domestic and external hard currency liabilities. In such cases, official lending provides the resources to pay off maturing debts; existing foreign currency debts are temporarily replaced by new official debt. Over time, the country is expected to be able to reaccess capital markets and to borrow again in foreign currency. Such official lending leaves the amount of foreign currency debt on the country's balance sheet unchanged, but increases the amount of preferred debt (incidentally worsening the capital structure). Relevant examples include official financing packages to help Mexico finance payments on the government's maturing tesobonos at the end of 1994, and to help Korean monetary authorities supply foreign exchange to banks experiencing difficulties rolling over their short-term bank lines at the end of 1997.

- Second, the private sector or the government of the country can experience difficulties in refinancing local currency denominated debts, or obtaining needed new domestic financing on terms consistent with medium-term sustainability. ${ }^{24}$ In principle, such difficulties can be overcome through domestic monetary expansion, as the central bank lends to the government or the banking sector the local currency that they need to meet their maturing obligations. But the ability of the domestic lender of last resort to increase the money supply - with the associated pressure on the exchange rate - may be limited by the presence of sectoral currency mismatches. For example, the government may be having difficulty rolling over domestic currency denominated debt, but the central bank's room to increase the money supply may nonetheless be constrained because a sharp deterioration in the real exchange rate could threaten the solvency of the corporate sector, with implications for the banking sector. In such circumstances, foreign currency denominated lending from the official external sector can be used to take pressure off the domestic market, and to avoid the

${ }^{24}$ In practice, difficulty refinancing local currency denominated debt often is first reflected in a rise in local interest rates, and higher interest rates, in turn, can widen the budget deficit and risk generating unstable debt dynamics. Thus, it can often be difficult to distinguish between a pure domestic "liquidity" crisis stemming from a maturity mismatch and an incipient "solvency" crisis stemming from higher interest rates and debt with a short duration. 
need to expand the domestic money supply in response to a sector's difficulties in rolling over domestic currency denominated debt. Such financing necessarily implies an increase in the government's exposure to currency risk. It also can result in an increase in the country's aggregate external liabilities, depending on whether the domestic currency debt that is not being rolled over is held by residents or nonresidents. $^{25}$

Nonconcessional official lending cannot, by definition, reduce the currency mismatch on the country's balance sheet as a whole. This is because it necessarily creates a foreign exchange denominated external liability. In some cases, however, official financing to meet a need for foreign currency liquidity stemming from a maturity mismatch can result in the transfer of currency risk from the private financial or corporate sector to the government. For example, the government could borrow externally from the official sector and sell the foreign exchange it receives, increasing the supply of the hard currency assets available to banks and firms. This facilitates the repayment of the private sector's short-term foreign exchange debt and indirectly limits the impact of the private sector demand for foreign exchange on the exchange rate. As a result, currency risk migrates from private firms to the government. ${ }^{26}$

Official lending cannot improve a country's capital structure or make a large contribution to reducing solvency risk. Capital structure mismatches arise from an imbalance between debt and equity financing. Official external support would only help a country's capital structure if extended as grants. In almost all cases, however, official support for emerging markets integrated into international capital markets takes the form of preferred creditor loans, which inherently creates a more rigid debt and capital structure. Official financing cannot improve the liability side of a country's balance sheet, it can only provide the country with time to adjust to strengthen its capacity to pay. This breathing space can be valuable. But ultimately, adding preferred loans to a country's balance sheet does not help if the country needs a substantial debt restructuring to regain solvency and debt sustainability.

${ }^{25}$ An example of an official financing package designed to help address difficulties in refinancing domestic debt is Russia's 1998 arrangement with the Fund, which was designed to help facilitate the refinancing of GKOs. This was done in the context of a quasi-fixed exchange rate regime which clearly limited the ability to expand the domestic monetary base. The same issue, however, can arise in the context of a float if there are limits on the scale of real depreciation that is possible without triggering a broader crisis.

${ }^{26}$ For example, in Turkey in 2001, official lending helped supply foreign assets to the government, which sold its borrowed foreign exchange in the process of financing its domestic fiscal deficit. The increased supply of foreign exchange helped Turkey's commercial banks to close an open currency position on their balance sheet. 


\section{Sustainability of Balance Sheets}

For official lending to be able to help meet a balance sheet need, the balance sheets of both the government and the country as a whole need to be sustainable. Their balance sheets must be strong enough, with needed adjustments, to support additional preferred debt to the official sector. ${ }^{27}$ The government's balance sheet matters even in cases where the underlying balance sheet problem arose on private balance sheets. A government that has a weak balance sheet is not in a position to help other sectors meet their balance sheet needs.

Determining the long-term sustainability of the government's and the country's balance sheets raises a number of specific problems. From a balance sheet perspective, long-term sustainability (in its simplest definition) requires that assets exceed liabilities. As discussed earlier, the major asset of the government is its long-term capacity to generate primary surpluses, and the major external asset of a country is its future capacity to generate surpluses in the non-interest bearing current account. The value of such assets depends on future growth, on the government's capacity to raise revenues, reduce expenditures and sustain fiscal adjustment, as well as the capacity of the country's residents to sell goods and services abroad. It also depends on the government's willingness to devote future resources to debt service rather than other priorities, and the country's willingness to run surpluses in the non-interest bearing current account to repay external debt. As a result, the major assets on the balance sheet of both the government and a country are illiquid and hard to value. Moreover, in a crisis, the government may assume the liabilities of other sectors, most notably the banking and financial system (by protecting depositors from losses). Hence, the government's sustainability often hinges on the scale of the government's contingent liabilities.

When deciding whether to lend, the external official sector will have to assess the government and country's solvency as well as its near-term liquidity position. The external official sector should only lend in the absence of a private debt restructuring when it believes that there is a sufficiently high probability that the government (on a sector level) and the country as a whole (on an aggregate level) are sustainable, provided needed adjustments are made. If the government and country are judged to be in an unsustainable position, a restructuring to reduce debts to a level consistent with a viable level of future adjustment is clearly appropriate. ${ }^{28}$

${ }^{27}$ In some cases, sustainability depends on external official financing. In the absence of relatively cheaper official financing from abroad, a country may be pushed into insolvency as the interest burden increases.

${ }^{28}$ This topic is addressed in depth in the recent Board paper on assessing sustainability, see $\operatorname{IMF}(2002 a)$. 


\section{Conclusions}

Economists have long understood the importance of looking at stocks as well as flows, notably in the context of monetary policy. There are nonetheless insights to be gained from trying to think more systematically about the role that financial balance sheets have played in recent crises in emerging market economies. Sharp changes in the stock of financial claims on a country that investors want to hold have been a feature of many recent crises. The underlying structure of the balance sheet also can help in understanding the impact of a sharp adjustment in demand for a country's financial assets, and the impact of the resulting adjustment in key asset prices_-notably the exchange rate.

This paper has sought to pull out a number of the insights and recommendations that emerge from the balance sheet analytical framework. The most important include:

- $\quad$ The currency and maturity structure of the outstanding debt stock is almost as important as the total size of the debt stock.

- Liabilities among residents can be a source of pressure on reserves, particularly if the liabilities are denominated in foreign currency.

- $\quad$ Sectoral balance sheets matter. Indeed, domestic crises - those arising from debts between residents - are particularly likely to snowball. The balance sheets of the government, the financial system and firms typically all interlink.

- $\quad$ Private actors should hedge against currency risk. But there are risks if the government is the primary source of the private sector's hedge: the underlying mismatch is passed to the government, and the private sector's gain in a crisis is the government's loss.

- A "domestic" balance sheet crisis will not stay "domestic" for long with open capital accounts. Residents and non-residents unwilling to hold domestic assets will seek to increase their holdings of foreign assets.

- $\quad$ The combination of short-term debt and foreign currency denominated debt is extremely dangerous. This is true even if one sector of the economy relies on shortterm domestic currency debt (creating a maturity mismatch) and another sector relies on longer-term foreign currency denominated debt (creating a currency mismatch). A currency mismatch anywhere in the economy constraints the government's capacity to act as a lender of last resort in domestic currency.

- $\quad$ Prompt action to contain a crisis before it starts to propagate across sectors can potentially avoid a larger, more devastating crisis.

- $\quad$ Financing need has to be assessed in relation to the outstanding stock of relevant claims, and thus the scale of financing needed to be effective may be large. At early 
stages of a crisis, the relevant stock may be financial claims on a single sector; at latter stages, it may be the financial claims on the entire country.

- $\quad$ There is a role for the external official sector to provide national authorities with reserves to meet demands for hard currency liquidity from domestic sectors experiencing financing difficulty. This includes intervention to provide the hard currency reserves to meet sectoral needs for liquidity arising from hard currency debts among residents. In the face of a surge in demand for hard currency liquidity, a country needs to hold a higher level of gross reserves to be able to intervene and still to maintain prudent cushion of reserves to cover other possible demands for hard currency liquidity.

- The ability of official intervention to offer a viable long-run solution to many problems rooted in poor balance sheets is limited. Preferred lending-particularly short-term lending - cannot radically transform a country's balance sheet or fundamentally improve its financial structure. It can augment the supply for hard currency available in the short-run to correct a temporary maturity mismatch and, by allowing the government to supply more hard currency to the economy, help the private sector to reduce its hard currency exposure. But adding a new senior debt intrinsically weakens the government's and the country's capital structure, and does not improve the aggregate currency position of the government or the country either. 


\section{Estimating BALANCE SheEt NeEDS: OPERATIONAL ISSUES}

Information about sectoral balance sheets, as well as the aggregate balance sheet of a country as a whole, can help to determine its balance of payments financing needs. Detailed information on the size, maturity and currency composition of the stock of assets and liabilities in the sectoral balance sheets is the first step toward calculating sectoral needs for foreign currency liquidity. Still this only gives an indication of the potential maximum need for foreign currency liquidity. Determining the actual balance of payments need requires making additional assumptions about the behavior of creditors and investors, such as the willingness of foreign banks to roll over short-term debt, the willingness of domestic depositors to keep dollar deposits in the domestic financial system and to maintain their foreign exchange position. It also requires determining which sectoral balance sheet needs could generate pressure on the reserves and the balance of payments.

The required information can be presented in a matrix that emphasizes intersectoral linkages as well as currency and maturity mismatches. ${ }^{29}$ Such a matrix is shown in Figure 1, Annex I and has been employed for the example of Thailand in the figures in Annex II. The rows contain the financial liabilities issued by the different sectors, broken down by maturity (residual basis) and currency, and, where applicable, issued equity is also reported. All liabilities or equity issued by the rest of the world to residents are normally denominated in foreign currency (in the matrix, these represent the external assets held by domestic residents, including the reserves of the monetary authorities). For most emerging markets, the debt liabilities that residents issue to the rest of the world are mostly denominated in foreign currency. The liabilities in each row are divided over the columns, according to the sector that holds the respective instruments. As the liabilities already represent consolidated sectoral data, the matrix's diagonal of intrasectoral holdings (e.g., the financial sector holdings of liabilities issued by the financial sector) remains empty. Since for the holder of a liability that liability constitutes an asset, the columns show a sector's assets. For example, the row Financial sector deposits and short-term liabilities, while reporting the liabilities that domestic banks (might) have to repay in the short term, at the same time shows the liquid asset that corporations and households have in the form of bank deposits. Additional rows with memorandum items may cover off-balance sheet activities

\footnotetext{
${ }^{29}$ The classification of sectors is not fully identical to that used in the 1993 System of National Accounts (SNA): In order to (i) be able to analyze the financial sector's balance sheet without the assets and liabilities of the monetary authorities (usually holder of large reserve assets), and to (ii) reflect the political reality that the monetary authorities can be expected to act as part of the government (budget authorities) in an emerging market crisis, the monetary authorities' balance sheet is included in the government sector (together with the general government) rather than being classified as part of the SNA's financial corporations' sector. Further, for simplification, financial and nonfinancial corporations (public and private), households and non-profit institutions serving households (the SNA's NIPSHs) are lumped together in the nonfinancial sector.
} 
Figure 1. Matrix of an Economy's Intersectoral Asset and Liability Positions

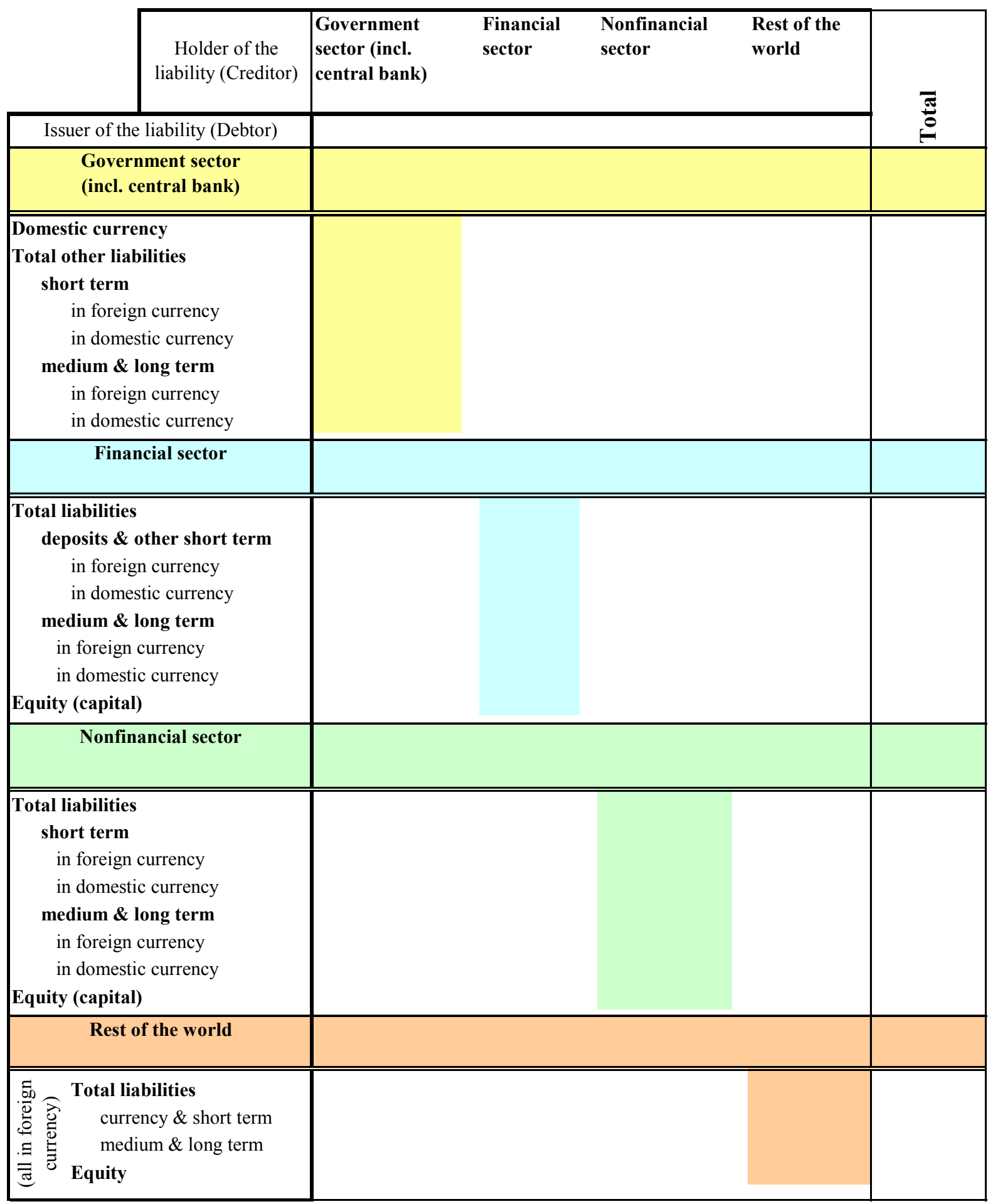


and contingent liabilities taken on by certain sectors; for example financial derivative positions or debt guarantees.

More complex ways of modeling financial balance sheets are of course possible. For example, concepts such as volatility could be incoporated more explicitly into the analysis; quantitative assessment could be made of the net equity position in the event of particular shocks etc. The advantage of the matrix outlined here is that it highlights key sources of vulnerability and inter-linkages at a point in time, based on relatively uncomplicated information and without requiring extensive modeling.

Even with all the basic information for the matrix principally available, important conceptual issues remain. When applying the balance sheet approach to concrete country cases, practical problems arise, in particular with regard to the valuation of assets. State enterprises, for example, are indeed tangible assets, but their valuation is nearly as difficult as the estimation of the country's ability to generate surpluses over the long-run. The valuation of private sector balance sheets is also not always straightforward, even if the fundamental data is available. For example, nonfinancial assets (e.g., fixed assets), some of which may be nontangible (e.g., goodwill) are often as important as they are difficult to value. While solvency in the private sector is a matter of present and future cash flow, this may be of little guide to the liquidation value of many firms. A further challenge is how to assess the risks associated with various components of balance sheets (e.g., the availability of assets to confront a crisis, and the question of which liabilities create higher risks). Consequently, the balance sheet approach will have to be implemented flexibly, taking into consideration the quality and often simply the availability of data.

In practice, the dearth of relevant data in most member countries presents an obstacle to any numerical application of the balance sheet approach. Balance sheet information has not been among the statistics routinely produced and disseminated by national authorities. This is mainly due to resource constraints regarding the compilation of data, although confidentiality concerns also play a role. Nevertheless, as mentioned above (Box 4) during the past few years, such information has become more readily available, partly due to the Fund staff's increasing focus on stock data as well as efforts to promote transparency and data dissemination. Indeed, central banks and statistical agencies in some emerging economies have started to collect sectoral balance sheet data, including the corporate sector. Such information should become more readily available as more countries subscribe to the SDDS and improve their compilation of external debt statistics. ${ }^{30}$ As a

${ }^{30}$ The new External Debt Statistics: Guide for Compilers and Users which was jointly produced by eight international agencies, is the international standard designed to assist member countries to collect much of the data pertinent to the balance sheet approach. The Guide emphasizes stock data, and the compilation and presentation of external debt data both on a sectoral basis and an aggregate basis. It provides concepts (Chapter 6) and presentation tables (Chapter 7) for measures such as: (i) remaining maturity basis, (ii) currency of denomination, (iii) the external debt service payment schedule and (iv) the net external debt 
general rule, however, data availability might often not yet be sufficient to make the balance sheet an operational tool for estimating financing needs. Selected country teams may use the approach on an experimental basis, with modest implications for staff resources.

\section{Although there is no standardized balance sheet data set, a number of sources provide partial information. These include: ${ }^{31}$}

- Information collected and disseminated by the national authorities directly is the most valuable point of reference. In cases where this information might not yet be published on these institutions' websites or elsewhere, it may be available to IMF staff in the context of the Fund's surveillance activities, including Article IV consultations and FSAPs.

- The country pages in the IMF's International Financial Statistics provide, inter alia, monthly information on the international liquidity situation of the monetary authorities, reported holdings of foreign exchange, SDR, and reserve positions with the Fund. Where significant, the monetary authorities' other foreign assets (e.g., balances under bilateral payments agreements of central banks) and liabilities (other than use of Fund credit), as well as foreign accounts of financial institutions other than the monetary authorities are also reported. The Money and Banking section contains more detailed domestic currency denominated statistics on the claims and liabilities of the monetary and other financial institutions: demand, time and savings deposits, but often also foreign currency deposits. Importantly, in presently 78 countries the IFS includes the International Investment Position (IIP) ${ }^{32}$ which

position. The Guide also incorporates equity and financial derivative positions into external debt positions (through their identification as memorandum items). Of course, as this paper argues, examination of external debt alone (i.e., debt held by non-residents) is insufficient to do a full assessment of balance sheet risks. A full assessment requires examining the risks associated with the structure of the existing stock of domestic debts of various sectors of the economy, as well as the risks associated with their external debts.

${ }^{31}$ Other international sources exist, but are less useful as they have been designed to report only on specific aspects of a country's balance sheet. These include: (i) the World Bank's debt tables (Global Development Finance), which provide only limited information about private sector assets and liabilities; (ii) the United Nations statistical publications (National Accounts Statistics: Main Aggregates and Detailed Tables), which report sectoral balance sheet information for only very few developed countries; (iii) the OECD's statistical publications, which do not include sectoral balance sheet information at all (See Beghum, Khamis, and Wajid (2002)).

32 More detailed IIPs than in the IFS are available in the Balance of Payments Statistics Yearbook. From mid-2002 all countries that have subscribed to the SDDS are expected to disseminate their IIP and to publish quarterly external debt data. Further balance sheet data 
provides information on the financial assets and liabilities of a country vis-à-vis the rest of the world. The first IIP subclassification is by function (e.g., direct investment, portfolio investment, reserves, financial derivatives and other investment), but also by sector (monetary authorities, general government, banks and other sectors). In addition, the IIP usually includes some information on the maturity structure of these foreign asset and liability positions.

- $\quad$ The BIS international banking statistics provide quarterly creditor-side statistics on the assets and liabilities of banks in the 28 countries and territories that report to the BIS. In some emerging markets, such as Brazil, Philippines, Russia, and Turkey, however, the borrowing from BIS area banks only presents about one third of the total external debt as measured by the World Bank's debt tables. ${ }^{33}$ The BIS data disaggregate claims into bank and nonbank sector (including domestic foreigncurrency denominated debt), and thus allow to analyze some sectoral vulnerabilities. Importantly, the maturity breakdown is reported by residual maturity rather than original maturity - unfortunately, however, only on an aggregated country basis, which does not allow for a search for maturity mismatches on the sectoral level.

Together, the IFS and BIS data provide reasonable coverage of the public sector's liabilities and liquid assets, and of the country's aggregate external liabilities. Nonetheless, many white spots remain in the sectoral balance sheet template due to a lack of information on the residual maturity of the external liabilities in the different sectors. ${ }^{34}$ Importantly, following the residence principle used for all balance of payments data, the IIP only reports liabilities to nonresidents, regardless of the currency denomination. While it can be assumed that debt issued to nonresidents typically is denominated in foreign currency (although in some countries foreign investors may be willing to hold domestic currency debt), there is often little data with regard to foreign currency items that do not involve nonresidents. Finally, there is a general paucity of data on assets and liabilities in the nonfinancial private sector, including corporations.

(e.g. on the banking sector) might also be available in other IMF documentation (Staff Reports, Statistical Appendices, FSAPs etc.).

${ }^{33}$ For a comparison of the two databases see Dixon, Haldane, and Hayes (2001). As shown below, in the case of Thailand BIS data show external debt of $\$ 70$ billion at end-1996 as opposed to over $\$ 110$ billion according to the authorities and Fund staff estimates.

${ }^{34}$ If at all, typically, original rather than residual maturities are reported. Although short original maturity guarantees a short residual maturity, information on original maturity does not provide an indication of how much medium to long-term debt is maturing in the near term. For purposes of assessing demands on foreign currency reserves, residual maturity is the more useful concept. This requires to know the amortization profile of the debt stock in addition to its original maturity. 
The lack of information on the balance sheets of corporate borrowers is an important concern: The systemic risk emanating from corporations may be relatively small in countries where the domestic banking system has only limited exposure to the corporate sector (e.g., Mexico). In more typical cases, however, claims on corporations represent large portions of bank's balance sheets and the lack of data in this area is a serious shortcoming. In such cases, the result of stress testing banks' balance sheets for exchange rate and interest rate movements, as for example undertaken as part of the FSAP exercises, have to be interpreted with caution. 


\title{
Calculating Balance Sheet Risks and Financing Gaps: THAILAND BEFORE THE CRISIS
}

\begin{abstract}
A stylized analysis of Thailand's sectoral balance sheets at the outset of its 1997 crisis can illustrate both the scope for and the severe limitations of forecasts of external financing gaps. The choice of Thailand (using end-1996 and mid-1997 data) was motivated by several factors. First, this case is well documented both inside and outside the Fund, with non-standard data available to a greater extent than for other countries. Second, the crisis in Thailand originated in the private sector, which makes a sectoral analysis particularly useful. Finally, while the need for adjustment was recognized, the size of the capital account adjustment and possible financing needs was substantially underestimated; in fact, the original program's projection error was by far the largest among all crisis countries. ${ }^{35}$ Note, however, that the stylized calculations presented here are neither intended nor suited for a reexamination of the design of the Fund-supported program for Thailand in the summer of 1997. Rather, the exercise seeks to give an impression of the existing stock positions and the related vulnerabilities in end-December1996, and how they further built up through end-June 1997-just before the baht was floated (July 2, 1997) and the crisis unfolded. It does not track the large swings in the balance sheets (quantitative and valuation changes) that followed in the second half of 1997. If anything, the example shows how difficult it is, even with hindsight, to estimate a financing gap accurately.
\end{abstract}

A patchy picture of Thailand's financial vulnerabilities emerges (Figure 1 and 2). While the balance sheet does little to reveal the causes of vulnerabilities (in Thailand's case, for example, the quality of investments), it does highlight pressure points: for December 1996, short-term liabilities to the rest of the world were almost negligible in the government sector (less than $\$ 0.04$ billion), but huge in commercial banks (almost $\$ 29$ billion) and the nonbank sector (almost $\$ 19$ billion). ${ }^{36}$ Assuming that these liabilities were denominated in foreign currency, on the aggregate, Thailand had roughly $\$ 48$ billion short-term foreign currency debt. On the asset side, the monetary authorities - Bank of Thailand (BOT) - held close to $\$ 39$ billion foreign reserve assets. At the same time, however, the BOT already had

\footnotetext{
${ }^{35}$ For a comparison see Lane and others, (2002); p. 10, Table 3.2, which puts the projection error for the 1998 capital account adjustment at over 17 percent of GDP.

${ }^{36}$ Readily available data on commercial banks is used, in order to avoid difficulties of properly consolidating the data for the entire financial sector (as presented in the general template above).Therefore, finance companies and other financial institutions are included in the nonbank sector (the nonfinancial sector in the general template), together with corporations and households. The commercial banks' data includes the operations of the Bankok International Banking Facility (BIBF).
} 
Figure 1. Thailand: Intersectoral Asset and Liability Position

End of December 1996

\begin{tabular}{|c|c|c|c|c|c|}
\hline $\begin{array}{c}\text { Holder of the } \\
\text { liability (Creditor) }\end{array}$ & $\begin{array}{l}\text { General } \\
\text { government and } \\
\text { BOT }\end{array}$ & $\begin{array}{l}\text { Commer. } \\
\text { Banks }\end{array}$ & $\begin{array}{l}\text { Nonbank } \\
\text { sector }\end{array}$ & $\begin{array}{l}\text { Rest of the } \\
\text { world }\end{array}$ & $\stackrel{\pi}{0}$ \\
\hline $\begin{array}{c}\text { General government and Central } \\
\text { bank (BOT) }\end{array}$ & & & & & \\
\hline $\begin{array}{l}\text { Domestic currency } \\
\text { Total other liabilities } \\
\text { short term } \\
\text { in foreign currency } \\
\text { in domestic currency } \\
\text { medium \& long term } \\
\text { in foreign currency } \\
\text { in domestic currency }\end{array}$ & & $\begin{array}{l}2,394 \\
\mathbf{5 , 5 5 5} \\
\mathbf{3 , 6 1 6} \\
\\
3,616 \\
1,939 \\
\\
1,939\end{array}$ & 11,885 & $\begin{array}{r}5,152 \\
34\end{array}$ & $\begin{array}{r}14,279 \\
\mathbf{1 0 , 7 0 7} \\
\mathbf{3 6 5 0} \\
\\
7,057\end{array}$ \\
\hline $\begin{array}{r}\text { Commercial Banks } \\
\text { BIFB) }\end{array}$ & & & & & \\
\hline $\begin{array}{l}\text { Total liabilities } \\
\text { deposits \& other short term } \\
\text { in foreign currency } \\
\text { in domestic currency } \\
\text { medium \& long term } \\
\text { in foreign currency } \\
\text { in domestic currency } \\
\text { Equity (capital) }\end{array}$ & $\begin{array}{r}\mathbf{1 0 , 3 2 7} \\
\mathbf{9 , 3 6 6} \\
9,366 \\
961\end{array}$ & & $\begin{array}{c}\mathbf{1 3 9 , 2 9 9} \\
\mathbf{1 3 1 , 8 6 6} \\
448.2 \\
131,417 \\
7,434 \\
7433.7\end{array}$ & $\begin{array}{r}\mathbf{4 8 , 7 9 0} \\
\mathbf{2 8 , 8 5 8} \\
28,189 \\
669 \\
19,932\end{array}$ & $\begin{array}{r}\mathbf{1 9 8 , 4 1 7} \\
\mathbf{1 7 0 , 0 9 0} \\
28,637 \\
141,453 \\
28,327 \\
\\
\\
23,439\end{array}$ \\
\hline Nonbank sector & & & & & \\
\hline $\begin{array}{l}\text { Total liabilities } / 2 \\
\text { short term } \\
\text { in foreign currency } \\
\text { in domestic currency } \\
\text { medium \& long term } \\
\text { in foreign currency } \\
\text { in domestic currency } \\
\text { Equity (capital) }\end{array}$ & & $\begin{array}{r}\mathbf{2 0 6 , 7 1 5} \\
555.2 \\
31,542\end{array}$ & & $\begin{array}{r}\mathbf{6 1 , 7 0 1} \\
\mathbf{1 8 , 8 3 1} \\
18,831 \\
42,870 \\
42,870 \\
4745\end{array}$ & $\begin{array}{r}\mathbf{2 6 8 , 4 1 6} \\
\mathbf{1 8 , 8 3 1} \\
\\
42,870 \\
42,870 \\
136,252\end{array}$ \\
\hline Rest of the world & & & & & \\
\hline 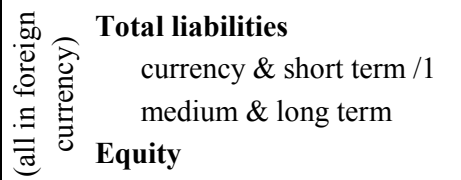 & $\begin{array}{l}\mathbf{3 8 , 6 9 4} \\
38,694\end{array}$ & $\begin{array}{l}7,029 \\
2,580 \\
4,449\end{array}$ & 481 & & $\begin{array}{r}45,723 \\
41,274 \\
4,449\end{array}$ \\
\hline
\end{tabular}


Figure 2. Thailand: Intersectoral Asset and Liability Position

End of June 1997

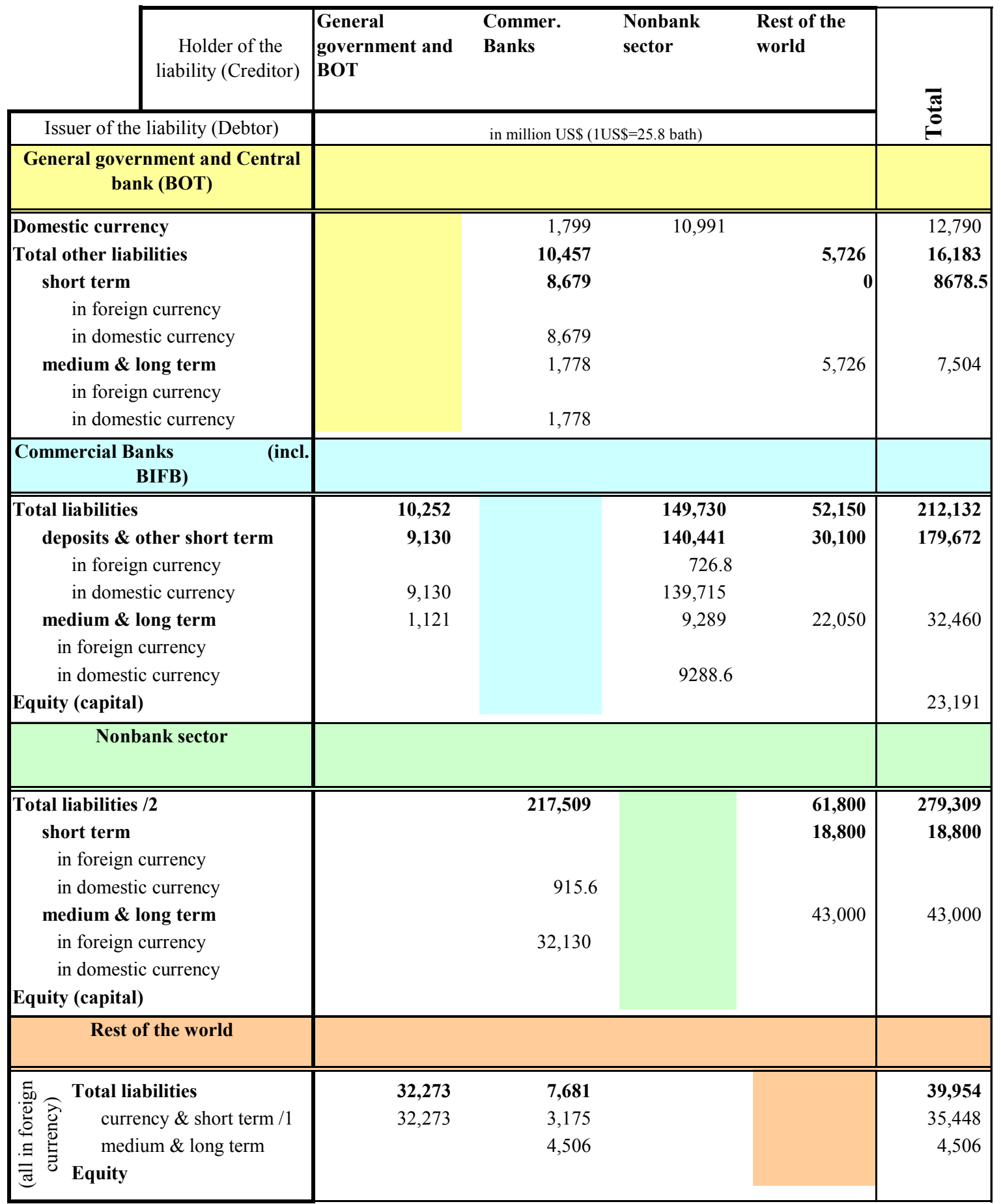


some outstanding forward and swap obligations, which, being off-balance-sheet activities, were not recorded on its regular balance sheet. ${ }^{37}$ The foreign assets of the banking system amounted to somewhat over $\$ 7$ billion, of which $\$ 2.6$ billion can be considered liquid (cash and deposits with nonresident banks), whereas the maturity of the rest remains unclear (reportedly most of it being "advances and bills" to banks and "export bills" to nonbanks). Further, commercial banks held about $\$ 207$ billion of claims on the domestic nonbank sector. Of these claims only a negligible part (about $\$ 0.5$ billion) were liquid deposits with other financial institutions, while little information exists about the maturity structure of the rest of the claims. With regard to the currency denomination of these claims, it is assumed that practically all lending to residents was in foreign currency, leaving commercial banks with an additional $\$ 32$ billion foreign currency assets in the form of claims against the domestic nonbank sector. At the same time, little information is available on the foreign asset holdings of the nonbank corporations and households, apart from their $\$ 0.45$ billion foreign currency deposits with the resident commercial banks.

Even with this partial information, however, a few conclusions on maturity and liquidity mismatches can be drawn for the situation of end-1996. The analysis shows that Thailand's potential financing needs were buried in the sectoral balance sheets other than the government, as indeed became clear only as the crisis unraveled in the second half of 1997.

- A potential financing gap of about $\$ 10$ billion existed between the government sector's foreign reserves and the country's total external foreign currency liabilities falling due over the short term. Assuming that none of the short-term debts would be rolled over (as investors would suddenly lose confidence in a crisis), and given that liquid foreign assets held by the commercial banks were less than $\$ 3$ billion, the nonbank sector would consequently have to have held $\$ 7$ billion liquid foreign assets to close the financing gap on the aggregate country level. This is, of course, a mere accounting exercise, as, unlike a central bank, private sector entities may not make their foreign assets available except for repaying their own debt.

- $\quad$ The maturity and currency mismatches of commercial banks with regard to nonresidents was enormous. Of the commercial banks' total liabilities ( $\$ 200$ billion) about one-fourth were foreign currency denominated (\$49 billion), of which 60 percent fell due in the short term ( $\$ 29$ billion). Under the-admittedly pessimistic - assumption that none of the short-term debt was rolled over, and

37 This and other similar Fund experiences throughout the financial crises in the 1990s, led to the preparation on the IMF's Data Template on International Reserves and Foreign Currency Liquidity (provisional guidelines in 1999 and a final version in 2001). The template integrates the concepts of international reserves and foreign currency liquidity in a single framework, thereby also covering off-balance-sheet activities, which can be a potential or predetermined drain on foreign currency reserves. Being a prescribed category in the Fund's SDDS, the template provides comprehensive reserve/liquidity data on participating countries. 
accounting for the liquid foreign assets ( $\$ 2.6$ billion), more than $\$ 26$ billion could end up constituting the sector's short-term financing need. Even if some of their other foreign assets (about $\$ 4.5$ billion) could be made liquid, the gap would remain substantial.

- Similar mismatches existed in the nonbank sector. Of the nonbank sector's liabilities ( $\$ 268$ billion) almost one-quarter ( $\$ 62$ billion) was owed to nonresidents in foreign currency — of which close to one-third (\$19 billion) was due in the short term. Even without the information about the sector's foreign assets holdings that would be needed to calculate the potential maturity and currency mismatches, it can be reasonably assumed that being less regulated than the commercial banks, nonbank corporations and households had even larger mismatches than the commercial banks.

- $\quad$ The commercial banks had indeed largely hedged their currency mismatch by onlending domestically in foreign currency: claims were about $\$ 32$ billion-over 15 percent of their total credit portfolio (\$207 billion) — in foreign currency against the domestic nonbank sector. Added to the $\$ 7$ billion in foreign assets, this largely offset the above described foreign currency mismatch the commercial banks had visà-vis nonresidents. In total, therefore, their balance sheets' foreign currency exposure seemed limited. The quality of this "hedge" of course depended critically on the quality of the domestic foreign currency claims.

- $\quad$ Thus, the currency risk was transferred to the domestic nonbank sector. The $\$ 32$ billion domestic foreign currency liabilities to resident commercial banks added to the nonbank sector's total $\$ 62$ billion foreign currency debt to nonresidents. And the share of these liabilities that fell due over the short term added to the immediate foreign currency need on account of the almost $\$ 19$ billion short-term liabilities to nonresidents. To the extent that the nonbank sector was unable to repay the credits from current foreign currency income (the real estate sector, which had assumed much of this debt, yielded little in export receipts) and/or by drawing down foreign currency assets ( $\$ 0.48$ billion of foreign currency deposits with resident banks and an unknown amount held abroad), the problem would bounce back to the commercial banks in the form of nonperforming loans.

\section{By June 1997, the potential financial gap had further widened-indeed,} dramatically so when accounting for the increase in the BOT's outstanding offbalance-sheet obligations. Whereas foreign liabilities in the commercial banks and the nonbank sector had largely remained unchanged in the period between December 1996 and June 1997 (commercial banks' total foreign liabilities had increased by about \$3 billion against an increase in assets of about $\$ 0.6$ billion), the government sector had lost almost $\$ 7$ billion of its foreign reserves. While this still left its reserves at over $\$ 32$ billion on the balance sheet, the BOT had over the same period increased its outstanding foreign currency 
Table 1. Thailand: External Foreign Currency Financing Gaps, December 1996 (In billion U.S. dollars)

Assuming only banks' foreign deposits were liquid and zero rollover of short-term liabilities

\begin{tabular}{lcccc}
\hline & $\begin{array}{l}\text { Government } \\
\text { Sector }\end{array}$ & $\begin{array}{l}\text { Commercial } \\
\text { Banks }\end{array}$ & Nonbank Sector & Country as Aggregate \\
\hline Liquid assets & 39 & 2.6 & $?$ & 41 \\
Short-term liabilities & 0 & 29 & 19 & 48 \\
Net & 39 & -26 & -19 & -7 \\
Including outstanding & 34 & -26 & -19 & -11 \\
swaps and forwards (-5) & & & & \\
\end{tabular}

Assuming all banks' foreign assets were liquid and 50 Percent rollover of short-term liabilities

\begin{tabular}{lcccc}
\hline & $\begin{array}{l}\text { Government } \\
\text { Sector }\end{array}$ & $\begin{array}{l}\text { Commercial } \\
\text { Banks }\end{array}$ & Nonbank Sector & Country as Aggregate \\
\hline Liquid assets & 39 & 7 & $?$ & 46 \\
Short-term liabilities & 0 & 15 & 19 & 34 \\
Net & 39 & -8 & -19 & 12 \\
$\begin{array}{l}\text { Including outstanding } \\
\text { swaps and forwards }(-5)\end{array}$ & 34 & -8 & -19 & 7 \\
\end{tabular}


Table 2. Thailand: External Foreign Currency Financing Gaps, June 1997 (In billion U.S. dollars)

Assuming only banks' foreign deposits were liquid and zero rollover of short-term liabilities

\begin{tabular}{lcccc}
\hline & $\begin{array}{l}\text { Government } \\
\text { Sector }\end{array}$ & $\begin{array}{l}\text { Commercial } \\
\text { Banks }\end{array}$ & Nonbank Sector & Country as Aggregate \\
\hline Liquid assets & 32 & 3.2 & $?$ & 35 \\
Short-term liabilities & 0 & 30 & 19 & 49 \\
Net & 32 & -26 & -19 & -14 \\
$\begin{array}{l}\text { Including outstanding } \\
\text { swaps and forwards } \\
\text { (-29) }\end{array}$ & 3 & -26 & -19 & -41 \\
\hline
\end{tabular}

Assuming all banks' foreign assets were liquid and 50 Percent rollover of short-term liabilities

$\begin{array}{lll}\text { Government } & \text { Commercial Nonbank Sector } & \text { Country as Aggregate } \\ \text { Sector } & \text { Banks } & \end{array}$

$\begin{array}{lcccc}\text { Liquid assets } & 32 & 7 & ? & 39 \\ \text { Short-term liabilities } & 0 & 15 & 19 & 34 \\ \text { Net } & 32 & -8 & -19 & 5 \\ \begin{array}{l}\text { Including outstanding } \\ \text { swaps and forwards }(-29\end{array} & 3 & -8 & -19 & -24\end{array}$

forward and swap obligations from about \$5 billion to some \$29 billion. ${ }^{38}$ Part of these swaps may have obligations to offshore entities from the government sector reserve assets. ${ }^{39}$ In

${ }^{38}$ Nukol Commission Report (1998), p. 64 and p. 103.

${ }^{39}$ For the lack of published data on the counterparties of these operations, it is assumed that all swaps and forwards were with offshore entities. 
particular for June 1997, this would result in a financing gap for the optimistic and the pessimistic scenario helped to hedge the foreign currency exposure of resident commercial banks, but to the extent that counterparts were nonresident entities, this implied a drain on foreign assets for the BOT and the country in aggregate. ${ }^{40}$

In light of the above, it becomes clear that any financing gap calculation is highly sensitive to behavioral assumptions, in particular the willingness to roll over shortterm debt. Two alternative capital account scenarios are presented below for both dates, December 1996 and June 1997: (i) assuming that commercial banks can neither roll over any short-term liabilities nor liquidate any foreign assets beyond their existing foreign deposits; (ii) assuming that commercial banks can secure a rollover of 50 percent of their short-term liabilities and liquidate all of their foreign assets. For both dates, an external foreign currency financing gap under the first scenario (\$7 billion in December, and $\$ 14$ billion in June) turns into surplus under the more optimistic second scenario ( $\$ 12$ billion and $\$ 5$ billion, respectively). Yet, all results look substantially worse if one subtracts the outstanding swap and forward of \$24 billion and \$41 billion, respectively. Of course, financing needs arise from the current account as well. In this case there was substantial scope for adjustment in the current account.

Beyond potential financing gaps, the template's data also indicates a capital structure mismatch in the nonbank private sector. Total liabilities in the nonbank private sector of about $\$ 269$ billion and equity of about $\$ 137$ billion imply an average debt-toequity ratio close to 200 percent at end-1996 (at the exchange rate of 25.6 baht to the U.S. dollar). While being a high ratio to begin with, it was even more significant in light of the high share of foreign currency debt: over a third of the total debt ( $\$ 94$ billion, including the foreign currency debt owed to domestic banks). Any sharp depreciation in the exchange rate would thus result in a sharp deterioration of the debt-to-equity ratio.

For the commercial banking sector as a whole a capital structure mismatch cannot be detected. For end-December 1996, the data suggests that commercial banks' liabilities amounted to close to 850 percent of the sector's capital, and the simple total capital to total asset ratio was over 10.5 percent. The data shows a deterioration by the end of June 1997, when the same ratios had worsened to over 910 percent, and less than 9.8 percent, respectively. This said, the ratio of 9.8 percent is not directly comparable to the

${ }^{40}$ Put simply, had only resident commercial banks been the counterparts to all the $\$ 29$ billion of swaps, they would have - also without being recorded on their balance sheets - entirely hedged their short-term foreign liabilities. The swaps would thus have been only a (future) shift of foreign assets from government sector to commercial banking sector, yet not a loss of these foreign assets for the country as a whole. To the extent that the swap and forward positions took place with offshore entities, however, they constituted an outflow. If resident commercial banks had been the counterparts, the assets would ultimately have flowed out too, but in the form of a repayment of their foreign liabilities. 
Table 3. Average Corporate Debt-to-Equity Ratios in Selected Countries (In percent)

\begin{tabular}{lcccccc}
\hline Thailand & Taiwan Province of China & United States & Germany & Malaysia & Japan & Korea \\
196 & 90 & 106 & 144 & 160 & 194 & 317 \\
\hline
\end{tabular}

BIS minimum capital asset ratio of 8.5 percent (for local banks), as it does not weigh the assets by risk.

Finally, some tentative assessments with regard to solvency risk can be made based on the template data. Although far from a comprehensive solvency analysis, comparing the available information on assets and liabilities to the appropriate flow figures yields some noteworthy observations:

- Commercial banks had a high solvency risk through their large exposure to the nonfinancial private sector. This exposure was high both relative to the exposure to the government sector (claims of over $\$ 206$ billion versus claims a little above $\$ 5.5$ billion) and in absolute terms (the total claims on nonbanks amounted to over 115 percent of GDP).

Table 4. Financial Institutions' Claims on the Private Sector in Selected Countries, End of 1996 (In percent of GDP)

\begin{tabular}{cccccccc}
\hline Thailand & Mexico & Turkey & Philippines & Indonesia & Brazil & Malaysia & Korea \\
142 & 22 & 24 & 48 & 55 & 31 & 144 & 66 \\
\hline
\end{tabular}

Note: Ratio for financial institutions (incl. Thai finance companies) used for international comparison; see Radelet and Sachs (1998), Table 14.

- In comparison, the solvency risk in the government sector seemed low.

Government sector debt (about $\$ 14$ billion) was equivalent to only about 6 percent of GDP and only about one-half of annual tax revenue collected by the central government. These ratios would about double when adding contingent liabilities in the form of $\$ 12$ billion government guarantees for state enterprise debt; even in the extreme case of adding the BOT's \$29 billion forward obligations (which 
nevertheless were fully covered by the BOT's own reserves), total public debt would still only reach 28 percent of GDP.

- Yet, a significant solvency risk on the aggregate country level was revealed when adding private and public sector external debt. Thailand's total external debt ( $\$ 115$ billion) reached over 60 percent of GDP and over 200 percent of the exports of goods and services. 


\section{REFERENCES}

Aghion, Philippe, Philippe Bacchetta, and Abhijit Banerjee, 2000, "Currency Crises and Monetary Policy with Credit Constraints" (unpublished; Cambridge, Massachusetts: Harvard University).

Burnside, Craig, Martin Eichenbaum, and Sergio Rebelo (Cambridge, Massachusetts: National Bureau of Economic Research). 1998, "Prospective Deficits and the Asian Currency Crisis,” NBER Working Paper No. 6758.

Bussière, Matthieu and Christian Mulder, 1999, "External Vulnerability in Emerging Market Economies: How High Liquidity Can Offset Weak Fundamentals and the Effects of Contagion,” IMF Working Paper 99/88 (Washington: International Monetary Fund).

Calvo, Guillermo, 1998, "Capital Flows and Capital-Market Crises: The Simple Economics of Sudden Stops," Journal of Applied Economics, Vol.1, November, pp. 35-54.

Enrique Mendoza 1999, "Regional Contagion and the Globalization of Securities Markets," NBER Working Paper No. 7153, (Cambridge, Massachusetts: National Bureau of Economic Research).

Cavallo, Michele, Kate Kisselev, Fabrizio Perri, and Nouriel Roubini, 2002, "Exchange Rate Overshooting and the Costs of Floating," (unpublished; New York University).

Cespedes, Luis, Roberto Chang and Andres Velasco 2000, "Balance Sheets and Exchange Rate Policy," NBER Working Paper No. 7840, August.

Chang, Roberto and Andres Velasco 1999, "Liquidity Crises in Emerging Markets: Theory and Policy,” NBER Working Paper No. 7272.

Cole, Harold, and Patrick Kehoe, 1996, “A Self-Fulfilling Model of Mexico’s 1994-1995 Debt Crisis,” Journal of International Economics, Vol. 41, November, pp. 309-330.

Corsetti, Giancarlo; Paolo Pesenti, and Nouriel Roubini 1999a, "What Caused the Asian Currency and Financial Crisis, Japan and the World Economy," September. 1999b, "Paper Tigers? A Model of the Asian Crisis," European Economic Review, July.

Diamond, Douglas and Philip Dybvig 1983, "Bank Runs, Deposit Insurance, and Liquidity,” Journal of Political Economy, Vol. 91, pp. 401-419.

Dixon, Liz; Andy Haldane, and Simon Hayes, 2001, "Measuring, Monitoring and Managing National Balance Sheets," Bank of England, (unpublished; London). 
Dornbusch, Rudiger 2001, "A Primer on Emerging Market Crises," available on the web at (http://www.mit.edu/ rudi/media/PDFs/crisesprimer.pdf)

Drazen, Allan and Paul Masson, 1994, "Credibility of Policies Versus Credibility of Policymakers," Quarterly Journal of Economics, Vol. 59, pp. 735-54.

Evans, Owen; Alfredo M. Leone, Mahinder Gill, and Paul Hilbers, 2000, Macroprudential Indicators of Financial System Soundnes, IMF Occasional Paper No.192, (Washington: International Monetary Fund).

Flood, Robert, and Peter Garber 1984, "Collapsing Exchange Rate Regimes: Some Linear Examples," Journal of International Economics, Vol. 17, pp. 1-13.

Friedman, Eric; Simon Johnson, and Tod Mitton, "Corporate Governance and Corporate Debt in Asian Crisis Countries," in Coe and Kim, eds. Korean Crisis and Recovery (IMF and Korea Institute for International Economic Policy, forthcoming)

Gertler, Mark, Gilchrist and Fabio Natalucci, 2000, "External Constraints on Monetary Policy and the Financial Accelerator," mimeo NYU

Ghosh, Atish; Timothy Lane, Marianne Schulze-Ghattas, Aleš Bulír, Javier Hamann, and Alex Mourmouras 2002, IMF-Supported Programs in Capital Account Crisis, IMF Occasional Paper No. 210 (Washington: International Monetary Fund).

Ghosh, Swati, and Atish Ghosh, 2002, "Structural Vulnerabilities and Currency Crises," IMF Working Paper 02/9 (Washington: International Monetary Fund).

Goldstein, Morris, 2002, "Managing Floating Plus," Policy Analysis in International Economics, \#66, Institute for International Economics, March 2002, Washington DC.

Gray, Dale, 2002, “Macro Finance: The Bigger Picture”, Risk Magazine, June 2002.

Hemming, Richard, Michael Kell, and Axel Schimmelpfennig, 2003. Fiscal Vulnerability and Financial Crisis in Emerging Market Economies. IMF Occasional Paper. Forthcoming

International Monetary Fund, 1993, Balance of Payments Manual, $5^{\text {th }}$ Edition, (Washington: International Monetary Fund).

1998, "World Economic Outlook: Financial Turbulence and the World Economy," October, (Washington: International Monetary Fund).

-2002a, "Assessing Sustainability," available at: www.imf.org

-2002b, "Data Provision to the Fund for Surveillance Purposes," available at: www.imf.org 
2002c, "Sovereign Debt Restructuring and the Domestic

Economy_Experience in Four Recent Cases," available at: www.imf.org

and World Bank, 2001, "Guidelines for Public Debt

Management," available at: $\underline{w w w . i m f . o r g}$

Inter-Agency Task Force on Finance Statistics (TFFS), 2001, "External Debt Statistics: Guide for Compilers and Users," unpublished-final draft, November, http://www.imf.org/external/np/sta/ed/guide.htm.

Jeanne, Olivier and Charles Wyplosz, 2001, "The International Lender of Last Resort - How Large Is Large Enough?” IMF Working Paper No.01/76, May.

Johnston, R. Barry, Jingquing Chai, and Liliana Schumacher, 2000, “Assessing Financial System Vulnerabilities,” IMF Working Paper WP/00/76, April.

Kester, Anne Y., 2001, “International Reserves and Foreign Currency Liquidity: Guidelines for a Data Template."

Krugman, Paul, 1979, “A Model of Balance of Payments Crises," Journal of Money, Credit and Banking, Vol. 11, pp. 311-325.

Krugman, Paul, 1998, “Curfews On Capital Flight: What Are The Options?” (unpublished, MIT, October 12, http://web.mit.edu/krugman/www/curfews.html).

Krugman, Paul, 1999, "Balance Sheets, The Transfer Problem, and Financial Crises," (mimeo, MIT, January 1999, http://web.mit.edu/krugman/www/FLOOD.pdf).

Lindgren, Carl-Johan; Tomás Baliño, Charles Enoch, Anne-Marie Gulde, Marc Quintyn, and Leslie Teo, 1999, Financial Sector Crisis and Restructuring Lessons from Asia, IMF Occasional Paper No. 188 (Washington: International Monetary Fund).

Mendoza, Enrique, 2000, “Credit, Prices, and Crashes: Business Cycles with a Sudden Stop," this volume.

Mulder, Christian; Roberto Perrelli and Manuel Rocha, 2002, “The Role of Corporate, Legal and Macroeconomic Balance Sheet Indicators in Crisis Detection and Prevention,” IMF Working Paper 02/59, (Washington: International Monetary Fund).

Nukul Commission, 1998, “Analysis and Evaluation on Facts Behind Thailand's Economic Crisis." Bangkok: The Nation.

Obstfeld, Maurice; 1994, "The Logic of Currency Crises," Cahiers Economiques et Monetaires, Bank of France, Vol. 43, pp. 189-213. 
Ortiz, Guillermo, "Recent Emerging Market Crises-What Have We learned?" Per Jacobsson Lecture, 2002.

Pettis, Michael, 2001, “The Volatility Machine,” Oxford University Press.

Rodrik, Dani; and Andrès Velasco, 1999, "Short-Term Capital Flows," NBER Working Paper No.7364, September.

Sachs, Jeffrey and Steven Radelet, 1998, "The Onset of the East Asian Financial Crisis," NBER Working Paper No. 6680, August.

Schneider, Martin and Aaron Tornell, 2000, "Balance Sheet Effects, Bailout Guarantees and Financial Crises,” NBER Working Paper No.8060, December.

Sundararajan, V.; Charles Enoch, Armida San Jose, Paul Hilbers, Russell Krueger, Marina Moretti, and Graham Slack, 2002, Financial Soundness Indicators: Analytical Aspects and Country Practices, IMF Occasional Papers, No. 212 (Washington: International Monetary Fund). 